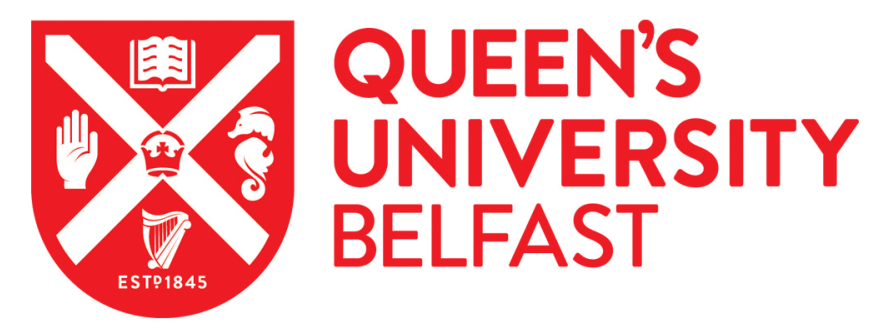

\title{
Reducing the resource acquisition costs for returnee entrepreneurs: Role of Chinese national science parks
}

Xia, S., Xiong, Y., Zhang, M., cornford, J., Liu, Y., Liu, M., Cao, D., \& chen, F. (2020). Reducing the resource acquisition costs for returnee entrepreneurs: Role of Chinese national science parks. International Journal of Entrepreneurial Behavior \& Research. https://doi.org/10.1108//JEBR-04-2019-0202

Published in:

International Journal of Entrepreneurial Behavior \& Research

Document Version:

Peer reviewed version

Queen's University Belfast - Research Portal:

Link to publication record in Queen's University Belfast Research Portal

Publisher rights

Copyright 2020 Emerald. This manuscript is distributed under a Creative Commons Attribution-NonCommercial-NoDerivs License

(https://creativecommons.org/licenses/by-nc-nd/4.0/), which permits distribution and reproduction for non-commercial purposes, provided the author and source are cited.

\section{General rights}

Copyright for the publications made accessible via the Queen's University Belfast Research Portal is retained by the author(s) and / or other copyright owners and it is a condition of accessing these publications that users recognise and abide by the legal requirements associated with these rights.

Take down policy

The Research Portal is Queen's institutional repository that provides access to Queen's research output. Every effort has been made to ensure that content in the Research Portal does not infringe any person's rights, or applicable UK laws. If you discover content in the Research Portal that you believe breaches copyright or violates any law, please contact openaccess@qub.ac.uk. 


\title{
Reducing the Resource Acquisition Costs for Returnee Entrepreneurs: Role of Chinese National Science Parks
}

\begin{abstract}
Purpose

The purpose of this paper is to empirically explore the mechanisms through which Chinese National Science Parks' (NSPs) services facilitate returnee entrepreneurs' (REs) acquisition of resources for their new ventures. Resource acquisition is crucial for new ventures but it inevitably leads to significant costs increase. Although the NSPs offer various services to REs to reduce these costs, they still struggle to find the right mix of services.
\end{abstract}

\section{Design/Methodology/Approach}

From the transaction cost's perspective, an exploratory multiple-case study was conducted with data collected from six NSPs in China.

\section{Findings}

The results reveal that four types of NSP services (mentoring \& training, social event, promotion of REs, and accreditation of Resource Holders (RHs) have both individual and joint effects on reducing REs' resource acquisition costs. Specifically, the 'accreditation of RHs' service directly helps REs reduce search costs. The combination of 'accreditation of RHs', 'promotion of REs' and 'social event' services helps REs and RHs to establish guanxi. Further, guanxi, working along with the 'mentoring \& training' service, helps REs to reduce contracting, monitoring and enforcement costs.

\section{Originality/Value}

This study is among the first to explore the matching mechanisms between science parks services and entrepreneurs' cost reduction. This helps reconcile the inconsistent findings on science parks' effect by explaining why some NSPs are able to provide strong support to REs while others are less successful. In addition, the findings are useful for NSPs to develop the right mix of tailored services for REs. Finally, REs will find this study useful to evaluate which NSP is a more suitable location for their new ventures.

Keywords: returnee entrepreneur; new venture; resource acquisition; science park; China 


\section{Introduction}

Since the Chinese State Council officially issued a guiding policy -Suggestions on Policy Implementation and Promotion of Mass Innovation and Entrepreneurship China witnessed an upsurge in international entrepreneurship. The phenomenon of Chinese Returnee Entrepreneurs (REs), i.e. individuals returning to China to establish new ventures after studying or working in other developed countries, has received more and more attention across multiple disciplines (Liu, 2010; Lin, 2016; Lin et al., 2019). It is argued that creating new ventures enables REs to bring back to China advanced technologies, skills and expertise. However, the survival and growth of such new ventures rest on access to various resources (Aldrich \& Martinez, 2007, Pickernell et al., 2011) and networking with local resource holders (RHs) is critical for REs (Lin et al., 2019). Unfortunately, REs typically lack domestic networks and knowledge because they have been living abroad for a long period of time (Li et al. 2012; Lin et al. 2016), which, as a result, inevitably generates significant costs for REs.

In recent years, Chinese National Science Parks (NSPs) introduced a wide variety of services and invested billions of RMB (Chinese currency) to support REs (Wang \& Miao, 2017), but the feedback from REs on different science parks' support packages had been divergent. Some REs were satisfied with the support from NSPs but some others found that they still did not get enough support to run businesses in China and were forced to leave China again (Wang and Miao, 2017). Scholars and practitioners are confused about why the significant investments of some science parks in services for RE have failed to generate the expected return (Liu \& Almor, 2016; Wang \& Miao, 2017). Further, there exists very mixed empirical findings on the effectiveness of science park services on entrepreneurs and ventures (e.g., Bakouros et al., 2002; Bruneel et al., 2012; Minguillo et al., 2015; Soetanto and Jack, 2013). In particular, we lack theoretical explanations of 
the underlying mechanisms by which NSPs support REs and therefore struggle to explain the performance variations between science parks. This theoretical puzzle triggered our research interest.

The objective of this study is to empirically explore the mechanisms through which Chinese NSP's services reduce resource acquisition costs for RE's new ventures. In particular, it addresses three research questions. First, which NSP services are demanded by REs to reduce their resource acquisition costs? Second, how can NSPs deploy bundles of services to match this demand for cost reduction? Third, why can some NSPs offer strong and effective support to REs, while others appear unable? We conceptualise REs' resource acquisition from RHs as a form of transaction and adopt the Transaction Cost Perspective (TCP) as the main analytical perspective, which has been proved effective in discussing science park incubation (Theodorakopoulos et al. 2014).

This study makes several contributions. Firstly, this study extends the literature on TCP by exploring the relationship between formal and informal governance structures in the context of REs' resource acquisition. Second, this study adds new insights into the SP literature by adopting a new view, the perception of entrepreneurs, to evaluate SPs' performance. Third, this study is among the first to explain the specific mechanisms by which SP services work individually or jointly to reduce REs' costs. Fourth, this study also provides explanation to the debate on science parks' impact on entrepreneurs. In terms of practical contribution, this study provides insights for NSPs on how to develop an appropriate combination of services that effectively help REs acquire resources for their new ventures. Further, REs can refer to this study to determine the best location for their new ventures by identifying which NSP offers the most appropriate mix of services. 


\section{Literature Review and Research Framework}

\section{Returnee Entrepreneurs (REs)}

In this study, the term Returnee Entrepreneurs (REs) refer to the individuals who return to China to start a business after at least two years of studying or working in OECD countries (Filatotchev et al., 2009; Li et al., 2012; Lin et al., 2016, Lin et al., 2019). Although many studies have contributed to the understanding of RE research, most of them tends to focus on the later stages of an RE firm's development in Chinese context (e.g., Filatotchev et al., 2011; Liu et al., 2010). Very few studies have examined REs' firms at their early stage and it is still unclear, therefore, how REs deal with resource acquisition costs at this stage of development of their ventures. Resources are important for entrepreneurs' new ventures to get through the difficult early stages (Aragon-Sanchez et al., 2017; Aldrich \& Martinez, 2007), and naturally the interaction with Resource Holders (RHs) is necessary for REs. RHs in this study refer to the decision makers of organisations which hold specific resources. The group of RHs includes suppliers, investors and service contractors and so forth. REs lack access to RHs because of their decayed domestic networks after living in foreign countries for a long time ( $\mathrm{Li}$ et al., 2012; Lin et al., 2016; Ma et al., 2019) and because REs' new ventures usually lack legitimacy and reputation. To overcome the above obstacles, the support from science parks is important for REs. Unfortunately, the extant literature has very limited understanding of how science parks can support REs (Lin et al., 2016; Filatotchev et al., 2011; Liu \& Almor, 2016).

\section{Science Parks}

Science Parks (SPs) are organizations with the goal of increasing the wealth of the local region by creating a favourable environment to support their tenant firms' 
innovation and development (Bakouros et al., 2002; Chan and Lau 2005). Research on SP has received growing interest in the last a few decades (Hobbs et al., 2017; Wang. et al., 2020). Recently, how to support entrepreneurs has become a significant topic for SPs (Diez-Vial and Montoro-Sanchez, 2017). Many SPs have followed the literature to input a lot resources and provide the various types of services for entrepreneurs, but some of them still cannot bring the expected benefits to entrepreneurs (Wang and Miao, 2017).

One reason is the analysis perspective bias. Specifically, many traditional studies tend to take the perspective of the SP (the service supplier), but, to some extent, ignore the view of the entrepreneurs (the service consumer) when evaluating SPs' performance. The perspective bias might become extremely serious when evaluating SPs' support to entrepreneurs' start-ups. SP's services usually cannot immediately translate into startups' financial and innovation performance improvement (Lecluyse et al., 2019). Therefore, the discussion on the effectiveness of SPs' services for start-ups needs to take more consideration into the perception of entrepreneurs. This new analysis perspective has been called for by some scholars (e.g. Falk, 2007; Lecluyse et al., 2019; Phan et al., 2005). But surprisingly, there are very few attempts in this direction. Actually, the research on the perceived value of entrepreneurs can enrich the insights into the actual benefits brought by SPs (Lecluyse et al., 2019). Further, this new research perspective can help explain why some SPs input a lot of services but still fail to satisfy their service consumers (entrepreneurs). For different types of entrepreneurs, SPs need to deploy different types of services. Most of the existing studies, however, fail to consider the service requirements of a special type of entrepreneurs - REs - who have different advantages and disadvantages, compared with local entrepreneurs (Li et al., 2012). In other words, the current studies have not yet clearly identified the types of services that REs demand (e.g. Xie et al., 2018). 
In addition to the analysis perspective bias, and there is no clear consensus on the effect of SP services on entrepreneurs (Lecluyse et al., 2019). Some researchers argue that those services positively influence entrepreneurs (e.g., Bruneel et al., 2012; Bøllingtoft, 2012; Mian, 2014; Soetanto and Jack, 2013), while others contend that they have little or even no effects (e.g., Minguillo et al., 2015). The key reason is that the existing literature tends to analyse the overall effect of SP services (e.g. Armanios et al., 2017; Xing et al., 2018), but fails to dig into the working mechanism of them (Figure 0). This issue calls for more in-depth insights into how SPs can provide effective services (Lecluyse et al., 2019).

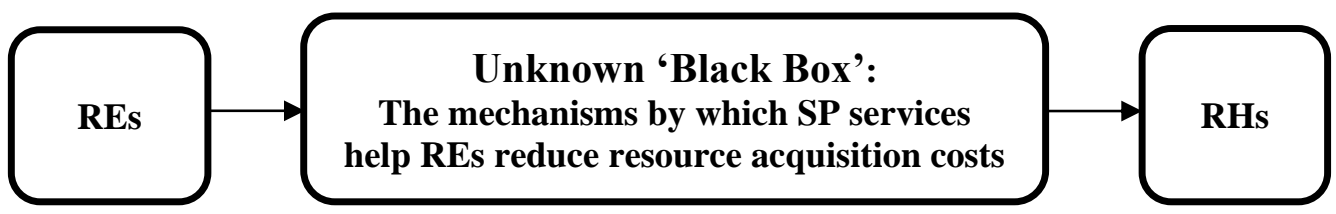

Figure 0: Research Framework-A

(Source: Created by the authors)

Some studies attempted to explore SPs' supporting mechanism via a wide range of services, including shared facilities, affordable offices (Bruneel et al., 2012; Chan and Lau, 2005), accounting support (Chan and Lau, 2005), access to funding and investment (McAdam and Marlow 2011; Theodorakopoulos et al., 2014), networking (Sa' and Lee, 2012), training sessions (Bruneel et al., 2012) and so on. But the generality of those findings' application context is somewhat low. It is because most studies focus on the effects of individual SP services, treated in isolation, while few researchers have considered the combined effects on entrepreneurs of a range of services (e.g., Bruneel et al. 2012; Soetanto and Jack 2013).

To help deal with above two serious limitations (perspective bias \& mechanisms) in the literature on SP, this study focuses on the perception of entrepreneurs and tries to explore the mechanisms by which SPs' multiple services jointly support a specific type 
of entrepreneurs, the REs. In the following, this study will first identify and summarize the types of SP services in Chinese context, and then adopt Transaction Cost Perspective (TCP) to create an analysis framework to explore the matching relationships between the SP services and the perceived support of REs.

\section{NSP's Services}

NSPs are home to over $50 \%$ of China's high-tech enterprises and firms linked to the NSPs contributed over 11\% to China's GDP in 2016 (Ministry of Science and Technology, 2017). Chinese NSPs not only takes governmental responsibility of managing the society, but also has the function of incubating firms. State and professional bodies are two primary actors shaping the modern institutional environment (Scott, 1987), and Chinese SPs are a combination of the two. The institutional voids, defined as the lack of market supporting institutions (e.g. intermediaries and legal protection)(Luo and Chung, 2013; Peng and Jiang, 2010), are a big challenge for REs to acquire resources in China. Therefore, the help of SP is quite important but, unfortunately, no research has detailed evidence on how exactly SPs' multiple services help entrepreneurs either jointly or individually (Figure 0). To explore this research question, the social and cultural context around SPs needs to be incorporated (Lecluyse et al., 2019). Guanxi fundamentally influences the business activities in China (Xin \& Pearce, 1996). Therefore, the findings based in advanced and western countries might not be applicable to Chinese SP (e.g., Bakouros et al., 2002; Bøllingtoft, 2012; Soetanto and Jack, 2013).

By taking account of Chinese context, this study first summarizes a variety of SP services discussed in the literature, and then combines similar services into overarching categories. Based on the interviews with REs, this study classifies four typical groups of services that are closely related to the resource exchanges between REs and RHs, 
including 'mentoring \& training', 'social event', 'promotion of REs' and 'accreditation of RHs' (Tables 1).

Table 1. Definition of four types of NSP services (Source: summarized by the authors)

\begin{tabular}{lll}
\hline \multicolumn{1}{c}{$\begin{array}{c}\text { Services } \\
\text { Offered by } \\
\text { NSPs }\end{array}$} & \multicolumn{1}{c}{ Definitions } & \multicolumn{1}{c}{ Examples } \\
\hline $\begin{array}{l}\text { Mentoring \& } \\
\text { Training }\end{array}$ & $\begin{array}{l}\text { Various programmes directly organized by NSPs to } \\
\text { facilitate REs to gain basic knowledge and skills on } \\
\text { venture creation and development }\end{array}$ & $\begin{array}{l}\text { Seminar, } \\
\text { Instruction }\end{array}$ \\
Social Event & $\begin{array}{l}\text { Various activities hosted by NSPs to facilitate REs to } \\
\text { access prospective RHs }\end{array}$ & $\begin{array}{l}\text { Conference, } \\
\text { Forum, Exhibition, } \\
\text { Party }\end{array}$ \\
Promotion of & $\begin{array}{l}\text { Various ways undertaken by NSPs to help REs to be } \\
\text { REs }\end{array}$ & $\begin{array}{l}\text { Political Honour, } \\
\text { Branding of NSPs }\end{array}$ \\
$\begin{array}{l}\text { Accreditation } \\
\text { of RHs }\end{array}$ & $\begin{array}{l}\text { Formal or informal database created by NSPs to help } \\
\text { REs evaluate RHs' basic background, such as } \\
\text { reputation }\end{array}$ & $\begin{array}{l}\text { Recommended list, } \\
\text { Blacklist }\end{array}$ \\
\hline
\end{tabular}

'Mentoring and training' refers to the services, such as seminars and courses focusing on developing REs basic skills in business management, negotiation and so on (Chan and Lau, 2005; Hughes et al., 2007; Lin et al., 2012; Peters et al., 2004), which are carried out by a NSP itself. 'Social event' refers to activities, such as conferences, exhibitions, and parties etc., organized by NSPs to provide REs access to prospective RHs. This category is similar to the networking opportunity in extant studies (e.g., Bøllingtoft, 2012; Chan and Lau 2005; Sá and Lee, 2012). 'Promotion of REs' refers to the actions conducted by NSPs to increase the trustworthiness or visibility of REs. This can be achieved either by helping REs to gain Chinese political posts (Cong et al., 2017), or REs' association with a prestigious SP (Chan and Lau 2005; Sá and Lee 2012). The final category of services concerns the 'accreditation of RHs.' This is significant for Chinese NSPs, but is largely neglected by the extant research park literature (e.g., Bøllingtoft, 2012; Bruneel et al., 2012). A strong 'accreditation of RHs' service was 
usually supported by a large and regularly updated database on RHs, and was in the form of recommendation (and, by omission, a 'black list').

\section{TCP and Research Framework}

The Transaction Cost Perspective (TCP) belongs to 'New Institutional Economics' originating in Coase (1937)'s seminal work and subsequently developed by Williamson (1985). We adopt TCP and conceptualize REs' resource acquisition from RHs as a form of external market transaction as RHs are outside the boundaries of REs' firms. TCP has been widely used to analyse how to deploy governance structures to reduce transaction costs (Dyer \& Chu, 2003; Poppo \& Zenger, 2002; Uzzi, 1997). In order to explore how NSP services help REs reduce their transaction costs, this study will examine the way NSP services influence the governance structures between REs and RHs, and then affect the transaction costs of REs. In the following, we will identify various types of transaction costs as well as the associated governance structures.

Transaction costs refer to all the costs incurred by exchanges between individuals (Williamson 1985). They include both ex ante (i.e. search and contracting) and ex post (i.e. monitoring and enforcement) costs. When collaborating with RHs, REs perceive all of these above costs (Table 2). In our data analysis, we have integrated monitoring and enforcement costs. The main reason is that these two types of costs are ex post costs and are usually entangled together. Therefore, NSP services tend to affect them simultaneously. The differentiation between the two types of costs requires a longitudinal perspective, and, as this study is a cross-sectional research, it is therefore not appropriate to disentangle monitoring and enforcement costs. For these reasons, many highly influential studies under TCP tend to either put together monitoring and enforcement costs as an item to discuss (e.g., Dyer and Chu 2003) or avoid the discussion or 
measurement of enforcement costs (e.g., Barthélemy and Quélin, 2006; Chiles and McMacking, 1996).

Table 2. Definition of the types of costs (Source: adapted from Williamson, 1985; Dyer and Chu, 2003)

\begin{tabular}{lll}
\hline RE's resource acquisition costs \\
\hline $\begin{array}{l}\text { Construct } \\
\text { Ex Ante }\end{array}$ & Search Costs & $\begin{array}{l}\text { Definition } \\
\text { Costs faced by REs in gathering information to identify } \\
\text { and evaluate potential RHs } \\
\text { Costs faced by REs in negotiating and writing a mutually } \\
\text { acceptable agreement with RHs }\end{array}$ \\
& $\begin{array}{l}\text { Contracting } \\
\text { Costs }\end{array}$ & $\begin{array}{l}\text { Costs faced by REs in monitoring the agreement to ensure } \\
\text { that RHs fulfill the pre-determined set of obligations }\end{array}$ \\
& Monitoring \\
Costs & Costs faced by REs in ex post bargaining and sanctioning \\
& Enforcement \\
Costs & RHs who do not perform according to the agreement \\
\hline
\end{tabular}

REs and RHs can rely on both formal (i.e. legal contracts) and informal governance structures (i.e. guanxi) to manage resource exchange (e.g., Dyer and Chu, 2003) (Table 3). A legal contract is usually a written agreement but guanxi does not require written materials and operates in an informal manner (Xin \& Pearce, 1996). Under the governance of guanxi, dispute resolution usually resorts to the transactors themselves (Uzzi, 1997), which is different from the condition of legal contracts, in which the third party enforcer, such as legitimate authorities, is the main channel to resolve disputes (Williamson, 1985).

Table 3. Definition of governance structures (Source: adapted from Dyer and Chu, 2003; Williamson, 1985)

\begin{tabular}{ll}
\hline Governance Structures \\
\hline Construct & Definition \\
Guanxi & $\begin{array}{l}\text { The relationship between two parties, which stands for a reciprocal } \\
\text { responsibility of each party to offer favor as a response to requests. } \\
\text { The enforcement of guanxi mainly depends on the two parties, and } \\
\text { as such it is a self-enforcement mechanism }\end{array}$ \\
\hline Legal Contracts & $\begin{array}{l}\text { Formal, written and legal agreements between two parties. The } \\
\text { enforcement of legal contracts resorts to a third party, such as a } \\
\text { court, and as such it is a non-self-enforcement mechanism }\end{array}$
\end{tabular}


In China's relationship-based society, guanxi is an important source of competitive advantage for doing business and it is often argued that guanxi can help stakeholders to open dialogues, exchange favours, and overcome institutional barriers (Tsang, 1998; Xin \& Pearce, 1996). Guanxi is usually built on either blood or social bases (Tsang, 1998). This paper focuses on the social base of guanxi between REs and RHs, which means the relationship among them is not familial.

The above sections have explained the three groups of constructs, including transaction costs, governance structures and NSP services. To explore the mechanisms by which NSP services help REs reduce resource acquisition costs, we need to analyse the observed patterns amongst the three groups of constructs. Considering that NSP services might either directly help REs decrease costs or enable REs and RHs to establish governance structures, such as guanxi and legal contracts, to control costs indirectly, we developed a research framework (Figure 1). The two governance structures in this framework refers to the collaborative pattern between REs and RHs, rather than the collaboration mechanism between NSPs and REs. Therefore, NSP services can sometimes directly help reduce the costs and do not necessarily have to go through the governance structures to influence the four costs. In addition, we will explore the relationship between the two governance structures based on REs' perspective. This will act as a foundation on which we can explore how NSP services help establish each of the two governance structures. This research framework will guide the following case studies to explore how to match the four types of services with the two categories of governance structures as well as the four types of resource acquisition costs. The extant literature has quite limited understanding of the function mechanism between NSP multiple services and REs' cost reduction. This paper is one of the first to explore this research question. 


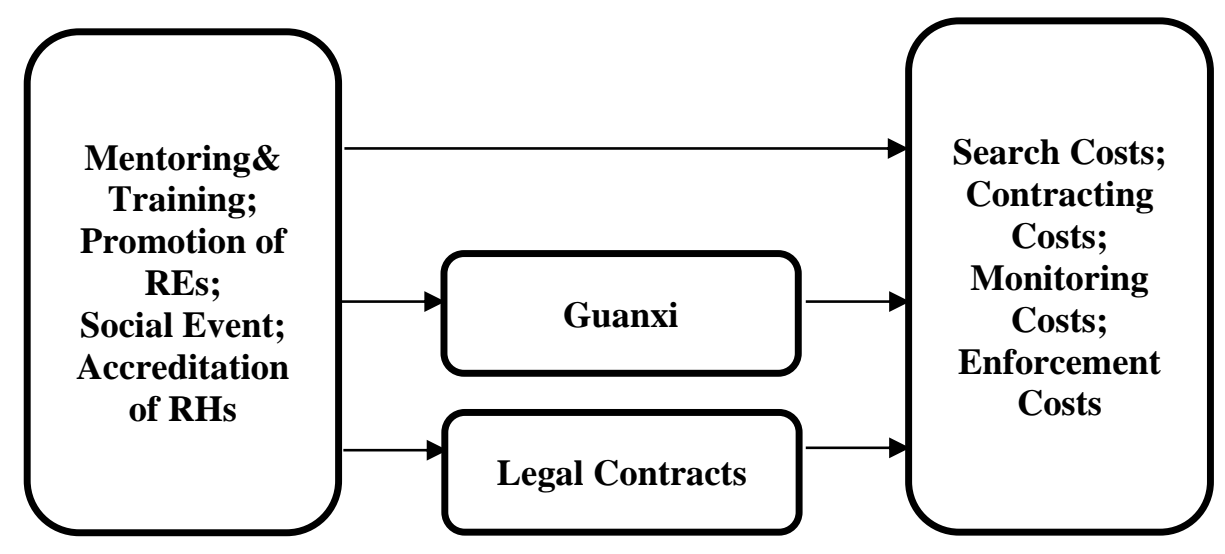

Figure 1: Research Framework-B

(Source: Created by the authors)

\section{Research Methods}

The extant literature has limited understanding of the classification of the SP services for REs (the first construct in figure 1), as well as of the specific mechanisms by which NSP services support REs' cost reduction in China (the relationships among the three constructs in figure 1). Therefore, it was appropriate to employ a qualitative multiplecase study approach, motivated by the exploratory research questions (Voss et al., 2002) and the contextual features associated with China.

\section{Case Selection and Description}

Theoretical sampling and replication logic were applied in case selection (Eisenhardt and Graebner, 2007). Specifically, extreme cases were selected purposively to ensure that they were particularly suitable in illuminating and extending relationships among constructs (Eisenhardt and Graebner, 2007). Further, the foundation of theory building from case studies is replication logic (Eisenhardt and Graebner, 2007, Yin, 2009). This study applied both literal and theoretical replication logic (Yin, 2009), which are presented at the end of this section. The unit of analysis in this study is the NSP. 
Both the internal and external environment of SPs are significant to their evolution (Phan et al., 2005), and they tend to determine the particular services developed for REs. Therefore, this study selected six NSPs based on two criteria. First, to reflect the internal characteristics of NSPs, four out of the six NSPs were selected from the group of Prospective World Top Class NSPs (PWTC-NSPs). These elite NSPs were appointed by Ministry of Science and Technology China (MoST) in 2006. Second, to reflect the external environment in which the NSPs were located, three NSPs came from the top urban agglomerations in China: Yangtze river delta and Pearl river delta. These two areas were the most developed regions in China (Jones Lang LaSalle, 2015). The other three NSPs came from ordinary urban agglomerations.

For anonymity, the six selected NSPs were labelled as A, B, C, D, E and F, respectively and they were further divided into four groups, labelled as 1, 2, 3 and 4 (Table 4). The groups 1 and 2 followed literal replication logic, on one hand, as they all belonged to PWTC-NSPs; on the other hand, these two groups were also in accordance with a theoretical replication logic as only group 1 came from the top urban agglomerations. A similar replication logic applied to the comparison between groups 3 and 4. Further, groups 2 and 4 were regarded as literal replication logic as they all came from the ordinary urban agglomerations. At the same time, these two groups followed theoretical replication logic as only the NSPs from group 2 were PWTC-NSPs. Similar replication logic applied to the comparison between groups 1 and 3. Finally, within group 1, NSP-A and B were accordant with literal replication logic. A similar logic was applied to the group 2, consisting of NSP-C and D. The profile of the six NSPs is provided in Table 5.

Table 4. Results of case selection (Source: created by the authors) 


\begin{tabular}{lll}
\hline $\begin{array}{l}\text { Located in Top Urban } \\
\text { Agglomerations }\end{array}$ & 1) NSP-A, NSP-B & 3) NSP-E \\
$\begin{array}{l}\text { Located in Ordinary Urban } \\
\text { Agglomerations }\end{array}$ & 2) NSP-C, NSP-D & 4) NSP-F \\
\hline
\end{tabular}


Table 5. Profile of six NSPs (Source: Reproduced with data from Official Websites and Yearbooks of NSPs and Ministry of Science and

Technology, 2014 and 2013)

\begin{tabular}{|c|c|c|c|c|c|c|}
\hline & NSP-A & NSP-B & NSP-C & NSP-D & NSP-E & NSP-F \\
\hline National Position & $\begin{array}{l}\text { PWTC } \\
\text { PW }\end{array}$ & $\overline{\text { PWTC }}$ & PWTC & PWTC & Ordinary & Ordinary \\
\hline City Located In & $\begin{array}{l}\text { Top urban } \\
\text { agglomeration }\end{array}$ & $\begin{array}{l}\text { Top urban } \\
\text { agglomeration }\end{array}$ & $\begin{array}{l}\text { Ordinary urban } \\
\text { agglomeration }\end{array}$ & $\begin{array}{l}\text { Ordinary urban } \\
\text { agglomeration }\end{array}$ & $\begin{array}{l}\text { Top urban } \\
\text { agglomeration }\end{array}$ & $\begin{array}{l}\text { Ordinary urban } \\
\text { agglomeration }\end{array}$ \\
\hline $\begin{array}{l}\text { Year of Entitled as } \\
\text { National Science } \\
\text { Park }\end{array}$ & 1992 & 1996 & 1991 & 1991 & 1992 & 1991 \\
\hline $\begin{array}{l}\text { Contribution to } \\
\text { Local City's GDP }\end{array}$ & $11 \%$ & $8 \%$ & $25 \%$ & $25 \%$ & $20 \%$ & $5 \%$ \\
\hline $\begin{array}{l}\text { Number of Tech- } \\
\text { Startups in } \\
\text { Incubation }\end{array}$ & 3148 & 1030 & 908 & 1157 & 221 & 137 \\
\hline $\begin{array}{l}\text { Number of Key } \\
\text { Intellectual } \\
\text { Property Rights } \\
\text { (IPRs) }\end{array}$ & 40736 & 74516 & 31608 & 32398 & 2938 & 9863 \\
\hline Key Industries & $\begin{array}{l}\text { Information } \\
\text { Technology, } \\
\text { Biology and } \\
\text { Medicine, Cultural } \\
\text { and Entertainment, } \\
\text { Low-Carbon } \\
\text { Industry }\end{array}$ & $\begin{array}{l}\text { Information } \\
\text { Technology, } \\
\text { Biology } \\
\text { Engineering, New } \\
\text { Material, Optical- } \\
\text { Mechano-Electrical } \\
\text { Integration Industry }\end{array}$ & $\begin{array}{l}\text { Information } \\
\text { Technology, } \\
\text { Biomedicine, } \\
\text { Aviation } \\
\text { Equipment, and } \\
\text { Environmental } \\
\text { Friendly Industry }\end{array}$ & $\begin{array}{l}\text { Information } \\
\text { Technology, High- } \\
\text { end Manufacturing, } \\
\text { Environmental } \\
\text { Friendly Industry }\end{array}$ & $\begin{array}{l}\text { Information } \\
\text { Technology, } \\
\text { Biology } \\
\text { Industry }\end{array}$ & $\begin{array}{l}\text { Information } \\
\text { Technology, } \\
\text { Biology and } \\
\text { Medicine, } \\
\text { Manufacturing } \\
\text { Industry }\end{array}$ \\
\hline
\end{tabular}




\section{Data Collection}

Multiple sources of evidence for this study included face-to-face interviews, official websites and documents of companies and NSPs. This allowed triangulation on important insights and strengthened the analysis (Yin, 2009). Semi-structured interviews were the main technique used because they enabled researchers not only to collect the real descriptions of interviewees, but also to explain the meaning according to the described phenomena(Yin, 2009). The research team interviewed two types of informants in each NSP, including REs and staff members of the NSP. In so doing, we acquired multiple perspectives from a variety of knowledgeable informants in each NSP (Eisenhardt and Graebner, 2007) (Appendix 1). Documents produced by both NSPs and REs' new ventures were also collected and analysed.

We initially made contacts with the directors of the innovation/entrepreneurship bureau/centre at the six NSPs, and with their assistance, we interviewed managers/staff members who were in the front line of serving REs. Furthermore, the managers/staff members introduced us to several qualified REs in each NSP to take part in the research. The REs were selected based on the following criteria. (1) To reflect the condition of the new generation of REs, i.e. only those who returned to China within the previous three years were included (2015 was the base year). (2) To reflect the focus on knowledge and technology transfer, only high-level REs who usually targeted high-tech industries were qualified to participate in this research. The definition of high-level REs in this study referred to the talent-related documents of the six NSPs. The specific description of highlevel REs varied in the six NSPs, but there was some consensus. For instance, REs could be classified in the high-level group only if they held a $\mathrm{PhD}$ degree, or served as a senior manager or researcher in a globally famous organization. (3) To reflect the most recent situation of NSPs, only RE ventures started in the previous two years were included (2015 
was the base year). (4) To make the comparison among the six NSPs more effectively, only RE ventures in the information technology sector were included, as this sector was not only a pillar industry in all of the six NSPs, but also absorbed a great number of REs, according to the six SPs' year book.

In the interviews, this study followed the practice of the bulk of the TCP literature (e.g., Walker and Weber 1984; Williamson, 1985) and based the measurement of costs faced by REs on their subjective perceptions and interpretation. This is accordant with the Austrian school of economics (e.g., Pasour 1991), which argues that economic costs are subjective because different decision makers based their judgements on different perceptions and preferences (Chiles \& McMackin, 1996).

The interviews, conducted in Mandarin, were guided by a semi-structured protocol (Appendices $2 \&$ 3) (Yin, 2009), which were initially developed based on the research questions, research framework and pilot study. The pilot interviews were carried out in November 2014 with two REs and two staff members of NSP-D. The length of each interview varied between approximately one and three hours and each interview continued until no new conceptual categories seemed to be generated.

In total, 49 face-to-face interviews were completed, including four that were conducted in the pilot research. Five REs in each NSP were interviewed, except the NSPF where there were only four REs who met our criteria of a qualified RE. In addition, three staff members of each NSP were interviewed in the main data collection except NSP-D where only one staff member participated since another two staff had already been interviewed in the pilot data collection. The main data collection was conducted between January and June 2015. A case database was developed by the research team members, which included interview transcripts, internet information and documents of NSPs and RE's firms. For the logic and contents, a draft report was reviewed by the 
research team members and four interviewees. The validity and reliability was ensured by taking a couple of measures throughout this study (see table 6) (Gibbert et al., 2008; Yin, 2009).

Table 6. Validity and Reliability (Source: created by the authors)

\begin{tabular}{|c|c|}
\hline $\begin{array}{l}\text { Validity and } \\
\text { Reliability Criteria }\end{array}$ & Case Study Practice \\
\hline Construct Validity & $\begin{array}{l}\text { 1. Multiple sources of data for triangulation (interviews, websites } \\
\text { and documents of companies and NSPs) (Section 3.2) } \\
\text { 2. A draft report was developed for the review by the team } \\
\text { members and four interviewees for contents and logic (Section } \\
\text { 3.2) } \\
\text { 3. A chain of evidence was developed (e.g. clarification of data } \\
\text { collection methods \& data analysis approaches, ) (Section 3.2) }\end{array}$ \\
\hline Internal Validity & $\begin{array}{l}\text { 1. This study was guided by research framework (Figure 1) } \\
\text { 2. A coding scheme guided the analysis (Section 4) } \\
\text { 3. Pattern matching logic was utilized to compare the predicted } \\
\text { and empirically identified patterns among constructs (Section } \\
\text { 5) }\end{array}$ \\
\hline External Validity & $\begin{array}{l}\text { 1. Case selection rationale was clear (Section } 3.2 \text { ) } \\
\text { 2. The case study was guided by transaction costs perspective } \\
\text { (Section } 3 / 4 / 5 \text { ) } \\
\text { 3. The case study context was clarified (Section } 3.1 \text { ) }\end{array}$ \\
\hline Reliability & $\begin{array}{l}\text { 1. Interviews were guided by a protocol (Appendices } 2,3 \text { ) } \\
\text { 2. A case database was developed, including interview transcripts, } \\
\text { internet information and documents of RE firms and NSPs } \\
\text { (Section 3.2) }\end{array}$ \\
\hline
\end{tabular}

\section{Within-Case Analysis}

In the within-case analysis, this study followed a protocol (Appendices $2 \& 3$ ) to evaluate REs' perceptions on NSPs' services and support. When one interviewee utilized some key words, such as effective, useful, helpful etc., then this study regarded the interviewee's opinion on the NSP's service or support as strong. Alternatively, this study considered the interviewee's view on the NSP's service or support as weak when they used other key words, such as dissatisfactory, insufficient and so on. Further, we preliminarily confirmed the REs' opinion by requiring them to explain why they thought NSPs' one given service or support was strong or weak. Interviewees' opinions were 
further verified against documents provided by them. When there was any inconsistency between the documents and the records of interviews, we contacted interviewees to find out the reasons and to re-confirm the opinion. The results of within-case analysis are presented in table 7. 
Table 7. Results on within-case analysis (Source: created by the authors)

\begin{tabular}{|c|c|c|c|c|c|c|}
\hline 1 NSPs' Service & NSP-A & NSP-B & NSP-C & NSP-D & NSP-E & NSP-F \\
\hline 1.1 Mentoring \& Training for & + & + & + & - & - & - \\
\hline \multicolumn{7}{|l|}{ REs } \\
\hline 1.2 Accreditation of RHs & + & + & - & + & + & - \\
\hline 1.3 Promotion of REs & + & + & + & + & - & - \\
\hline 1.4 Social Events & + & + & + & + & - & + \\
\hline 2 Governance Structures & NSP-A & NSP-B & NSP-C & NSP-D & NSP-E & NSP-F \\
\hline 2.1 Building of Legal Contracts & + & + & - & - & - & - \\
\hline 2.2 Building of Guanxi & + & + & - & + & - & - \\
\hline 3 Costs & NSP-A & NSP-B & NSP-C & NSP-D & NSP-E & NSP-F \\
\hline 3.1 Reduction of Search Costs & + & + & - & + & + & - \\
\hline 3.2 Reduction of Contracting & + & + & - & - & - & - \\
\hline Costs & & & & & & \\
\hline $\begin{array}{l}3.3 \text { Reduction of Monitoring and } \\
\text { Enforcement Costs }\end{array}$ & + & + & - & - & - & - \\
\hline $\begin{array}{l}\text { Note: } \\
\text { 1) All the results are based on the } \\
\text { 2) In the NSPs' Service Section, '- } \\
\text { 3) In the 'Governance Structures' } \\
\text { is weak. }\end{array}$ & $\begin{array}{l}\text { ption of } \\
\text { nds for th } \\
\text { Costs' se }\end{array}$ & $\begin{array}{l}\text { ach NSP; } \\
\text { es of NSF } \\
\text { +' stands }\end{array}$ & $\begin{array}{l}\text { ong, '- } \\
\text { upport o }\end{array}$ & $\begin{array}{l}\text { the ser } \\
\text { strong, }\end{array}$ & $\begin{array}{l}\text { NSPs ar } \\
\text { ads for th }\end{array}$ & of NSPs \\
\hline
\end{tabular}


NSP-A and NSP-B were both PWTC-NSPs and located in top urban agglomerations, and as such, they shared many similarities (Table 7). For instance, all the four types of services offered by both NSPs were perceived by REs as strong. When it came to the set-up of governance structures between REs and RHs, REs of both NSPs perceived strong help from NSPs (Table 7). For example, one RE from NSP-B commented that: 'On the platform of the NSP, I feel relatively safe and comfortable in trusting and establishing guanxi with [RHs], even though they were strangers to me beforehand.' In terms of the cost reduction, REs from both of these two NSPs argued that they received strong help (Table 7).

NSP-C and NSP-D were both PWTC-NSPs but were located in ordinary urban agglomerations. NSP-D was not seen as good at offering 'mentoring and training' services while NSP-C was seen as poor on 'the accreditation of RHs.' One RE from NSPC told the research team: 'When I was looking for angel investors, I usually worried about their capability and reputation even if after meeting them, and as such I had to check a huge number of files and consult many of my friends.' With regards to governance structures and costs reduction, NSP-D performed better than NSP-C in providing support to REs (Table 7).

Neither NSP-E nor NSP-F was PWTC-NSPs. NSP-E located in a top urban agglomeration while NSP-F was in an ordinary urban agglomeration. In these two NSPs, only one out of four services was perceived by REs as strong (Table 7). Although both of these SPs offered weak help for the set-up of REs' governance structures, NSP-E, at least, was perceived as helpful by its REs in reducing search costs (Table 7). For example, one RE from NSP-E commented: 'With the help of NSP-E, I can more easily check the basic background of suppliers, which facilitates me to more quickly exclude inappropriate 
options and narrow down a list on probable collaborators.'

\section{Cross-Case Analysis}

A cross-case analysis was conducted to explore the relationships among constructs and develop testable research questions. The pattern matching logic was used in the analysis (Gibbert et al., 2008). Specifically, we first developed the predicted mechanisms by which NSP support REs based on TCP and then compared it with the empirically identified ones. This process was significant to generalise the empirical findings and transform them into theoretical research questions (Yin, 2009). To develop each research question, we first established a draft relationship among constructs by summarizing REs' opinions and then verified that relationship by comparing the six SPs based on Table 7. Finally, we invited a couple of interviewees to review the established relationships and then confirmed relevant research question(s). The results are presented in Figure 2.

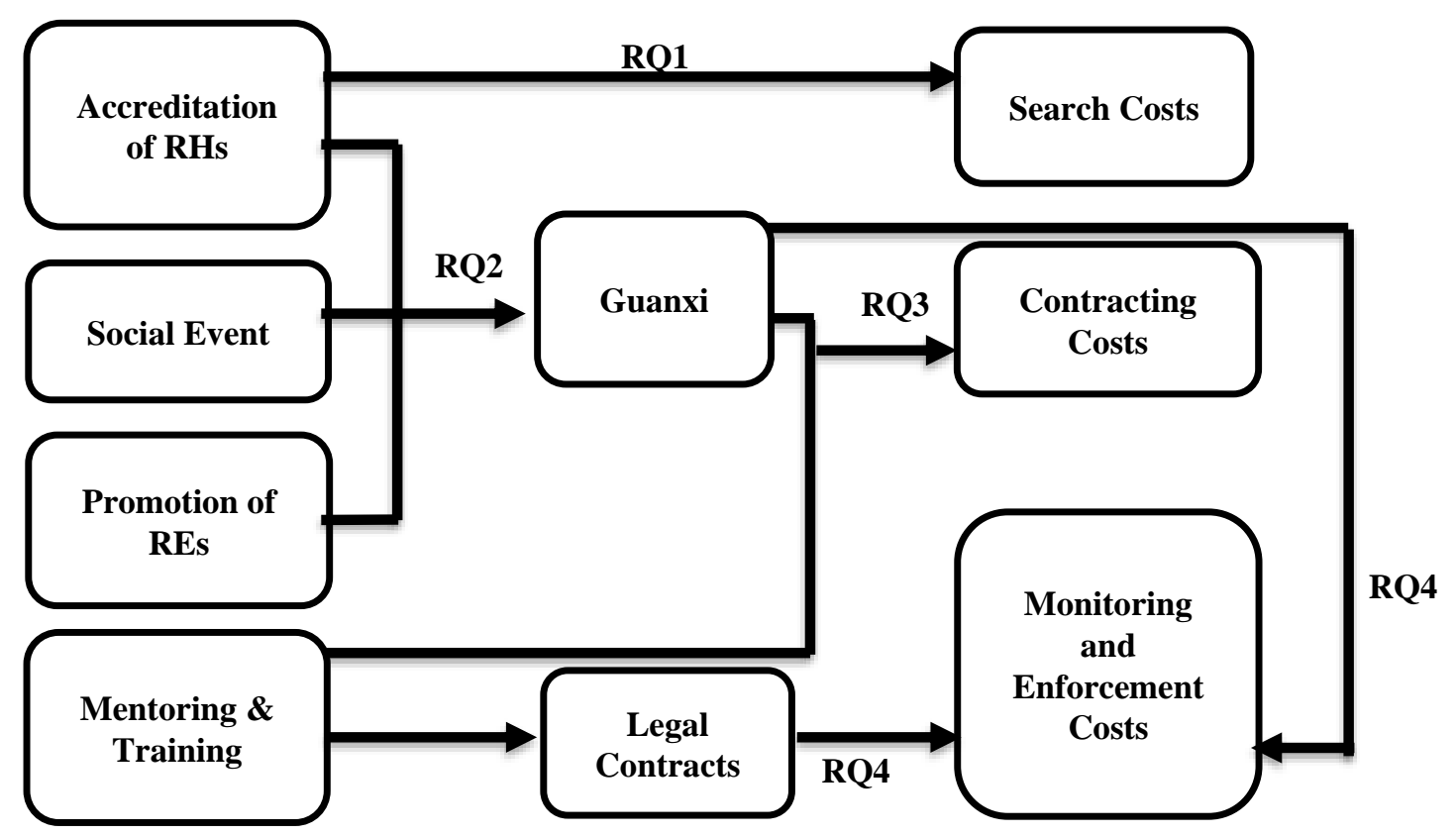

Figure 2: Summary on Findings

(Source: Generated by the Authors) 


\section{The Impact of NSP Services on Search Costs}

First, this study found that NSPs' 'accreditation of RHs' service alone helped REs screen RHs and significantly reduce search costs by more easily screening RHs (Figure 2). For instance, NSP-E offered a strong service on 'accreditation of RHs' but delivered weak services in other three aspects (Table 7). REs there regarded this support as an effective shortcut to narrow the journey of looking for appropriate RHs. On the contrary, without a strong service on 'accreditation of RHs', it appeared hard to reduce the search costs. For instance, REs from NSPs-C, which offered a weak 'accreditation of RHs' service but delivered strong services in other three aspects (Table 7), complained that they felt 'blinded' when looking for potential RHs. Second, we found that the effectiveness of the 'social event' service on reducing search costs depended on the presence of other services. The 'social event' service helped REs get access to RHs, but it did not offer sufficient support for REs to screen RHs' background. In our analysis, among the four services provided by NSP-F, only 'social event' was perceived strong by the REs, and REs there contended they did not get enough support from the NSP in searching for RHs. Third, there appeared to be little evidence that the 'mentoring and training' service was an effective tool to reduce search costs of REs. Although the benchmarking companies introduced in the 'training and mentoring' could be potential RHs, these big organisations usually did not have an interest in collaborating with new ventures. This was supported by REs from NSP-C, in which they got a strong 'mentoring and training' service but still perceived little help from the NSP in reducing search costs (Table 7). Fourth, we found that NSPs' 'promotion of REs' service could not guarantee the reduction of REs' search costs. NSPs' strong promotion for REs was reported to increase REs' credibility as perceived by potential RHs. However, the lack of information on the RHs still creates

many costs for REs in screening appropriate collaborators. This was supported by REs of 
NSP-C who felt they were offered a strong service on 'promotion of REs' from the NSP, but still perceived a weak help from the NSP in reducing the search costs (Table 7). Hence, we develop the following research question (Figure 2).

Research question 1: The strong 'accreditation of RHs' service directly helps REs reduce search costs.

\section{The Impact of NSP Services on Contracting Costs}

\section{'Social Event', 'Promotion of REs' and 'Accreditation of RHs' Services and} Guanxi

We found that an appropriate combination of three NSP services could facilitate the buildup of guanxi between REs and RHs who did not have prior knowledge of each other. First, this study found that even though 'social event' was important in building guanxi, this service alone could not, it seemed, guarantee it, which is in accordance with the argument of Tsang (1998). For example, among the four key services, NSP-F only delivered the strong service on 'social event', but it did not enable this SP to be helpful in supporting its REs to build guanxi with RHs (Table 7). The REs there reported that to build up guanxi, the social interaction was significant but not enough, and the verification of the potential partner's trouble-free character was necessary, which is in accordance with the view of Xin and Pearce (1996).

Second, we found that the 'accreditation of RHs' service helped REs build trust in RHs, but this service alone could not guarantee the establishment of guanxi between REs and RHs. A negative accreditation from NSPs might lead RHs to be banned by the NSP from doing business with its firms in the future, while a positive accreditation by NSPs would bring more opportunities to RHs. This, to some extent, could help REs build more trust in RHs. However, we found REs' trust in RHs could not guarantee that RHs 
trusted REs, which impeded the guanxi building between the two sides. For instance, NSP-E offered a strong service on 'accreditation of RHs' but delivered weak services on three other aspects, and as a result, its REs reported they tended to trust RHs but it could not ensure the establishment of guanxi with RHs.

Third, we found that the 'promotion of REs' service could increase REs' credibility and that of their new ventures, but it required the coordination of other services if the NSP tended to help build guanxi between REs and RHs. REs reflected that being trusted by RHs did not mean that RHs could be trusted. The one-way trust, pushed by the 'promotion of REs', was not enough to build guanxi between REs and RHs.

Building on the above analysis, this study found that the set-up of two-way trust, through the combination of 'promotion of REs' and 'accreditation of RHs', together with 'social event', enabled NSPs to offer strong help in building guanxi between REs and RHs. For instance, NSP-A, B and D, which offered strong services on 'promotion of REs', 'accreditation of RHs' and 'social event' simultaneously, could bring their REs strong help in the guanxi building. Nevertheless, although NSP-C delivered two strong services on both 'promotion of REs' and 'social event', its REs still perceived a weak help from the NSP in building guanxi with RHs. Hence, we develop the following research question (Figure 2).

Research question 2: NSPs effectively help the guanxi building between REs and RHs by combining the strong 'promotion of REs', 'accreditation of RHs' and 'social event' services.

\section{'Mentoring and Training' Service, Guanxi and Contracting Costs}

To explore the relationship among the 'mentoring and training' service, 'guanxi' and contracting costs, this study conducted analysis in three aspects. First, this study found that a relatively strong guanxi could accelerate the contract negotiation between REs and 
RHs, but it alone could not significantly reduce the contracting costs. For instance, NSPD delivered a strong help in guanxi building but failed to do so in offering the 'mentoring \& training' service. As a result, its REs reflected the SP provided a weak support to the contracts building and contracting costs reduction (Table 7). RE reported that guanxi could smooth the contract negotiation but could not substitute the role of the "mentoring \& training' service in offering REs knowledge on developing legal clauses. The closeness between two parties did not mean they knew how to design a proper legal agreement for both sides.

Second, this study found that NSPs' 'mentoring \& training' service could help REs speed up the process of designing a relatively complete and specific contract, but this service alone was not enough to significantly reduce contracting costs. For instance, NSP-C offered strong services on mentoring \& training but failed to give its REs strong help on the guanxi building with RHs. REs there perceived the SP's support to the contracting costs reduction, and accordingly the legal contract building, was relatively weak (Table 7).

Third, this study disclosed that the combination of 'guanxi' and the 'mentoring and training' service was beneficial to the contracting costs reduction, and the following is a comparison among NSP-A, B, C and D. As presented above, NSP-C delivered a strong service on 'mentoring and training' but was not good at helping REs build up guanxi. On the contrary, NSP-D could effectively help REs build up guanxi but was not good at delivering a strong service on 'mentoring and training'. Interestingly, neither NSP-C nor NSP-D offered strong help to their REs in reducing contracting costs and building up legal contracts (Table 7). By contrast, NSP-A and B were seen to be good at not only delivering a strong service on 'mentoring and training', but also helping REs build up 'guanxi'. As a result, both NSP-A and NSP-B were seen to be helpful in 
facilitating their REs to finalize legal contracts (Table 7). REs from the two NSPs agreed the importance of combining guanxi and 'mentoring \& training' service in reducing contracting costs. Hence, we develop the following research question (Figure 2).

Research question 3: The combination of strong 'mentoring and training' service and 'guanxi' enables REs to reduce contracting costs.

\section{The Impact of NSP Services on Monitoring and Enforcement Costs}

To find out the role of informal (i.e. guanxi) and formal (i.e., legal contracts) governance structures in reducing REs' monitoring and enforcement costs, this study conducted analyses in two aspects. First, we found that guanxi alone was not effective enough to reduce REs' monitoring and enforcement. In particular, the guanxi led REs to expend fewer resources in monitoring whether RHs followed the agreement. Even if there was a contingency, and as a result, renegotiations were required in the course of an agreement's enforcement, guanxi could make each party interpret the behaviour of other side as positive and thus reduce enforcement costs. However, REs reported that, to better reduce monitoring and enforcement costs, they still needed legal contracts in addition to guanxi. For instance, NSP-D was seen as providing strong support on guanxi building but not on the legal contracts building. REs there perceived the NSPs' help as weak in reducing monitoring and enforcement costs (Table 7).

Second, we discovered that it was hard to significantly reduce monitoring and enforcement costs by adopting legal contracts only. Specifically, through the design of relatively complete clauses, RHs' opportunistic behaviours could be mitigated to some extent, which decreased REs' monitoring and enforcement costs. However, the bounded rationality and uncertainty (Williamson, 1985) led REs and RHs to be unable to design perfectly complete legal contracts that can respond to every contingency. In this case, REs and RHs needed to use the other governance structure, guanxi, to coordinate their 
collaboration. REs reported that legal contracts could not substitute for guanxi's role in reducing monitoring and enforcement costs and that guanxi fundamentally influenced their behaviour, even if they had stayed in western countries.

Finally, this study found that when NSPs offered strong help in both the guanxi and legal contracts building, REs would perceive the SP as helpful in reducing their monitoring and enforcement costs. The instance could be found in NSP-A and NSP-B (Table 7), where REs agreed both guanxi and legal contracts were two crucial and complementary governance structures to manage the collaboration with RHs. Guanxi was seen as useful to make REs and RHs negotiate in good will. However, legal contracts acted as an ultimate approach to protect new ventures' vulnerability. Hence, this study develops the following research question (Figure 2).

Research question 4: The combination of guanxi and legal contracts building effectively helps reduce REs' monitoring and enforcement costs.

\section{Discussion}

This study has explored how to help Chinese NSPs design proper combinations of services to better reduce REs costs in the resource acquisition for their new ventures. To some extent, this helps to explain the puzzle of why some SPs can provide strong support to entrepreneurs while some others cannot. First, some NSPs tended to expand the categories of services but failed to identify the services required by REs. Based on six cases representing a range of NSPs, this study adds insights to research on SPs and RE by identifying that four key SP services (i.e. mentoring and training, social event, accreditation of RHs, and promotion of REs) closely matter to REs when they are acquiring resources from RHs. Second, some NSPs did not develop a combination of balanced high quality services. This study finds some NSPs are usually better at delivering the 'social event' and 'promotion of REs' services than providing the 
'accreditation of RHs' and 'training and mentoring' services. For instance, some NSPs have not yet recognized the extreme importance of the 'accreditation of RHs' service. Actually, the 'accreditation of RHs' service can not only directly help REs reduce search costs, but also indirectly help reduce contracting, monitoring and enforcement costs. Specifically, the reduction of contracting, monitoring and enforcement costs needs the built-up of guanxi, coupled with the 'mentoring and training' service. The establishment of guanxi requires both social interaction and a two-way trust between REs and RHs. Nevertheless, a weak 'accreditation of RHs' service cannot effectively help build up REs' trust in RHs, which, therefore, cannot help build up guanxi between REs and RHs. Also, some NSPs feel guanxi building is the foundation to help REs reduce contracting costs but unfortunately ignored the impact of trainings of REs. Finally, without the combination of the above four services, the joint implementation of guanxi and legal contracts might hard to be achieved, which weakens the effectiveness of REs' costs reduction on monitoring and enforcement.

\section{Conclusion}

\section{Implications for Theory}

This study makes contributions in three ways. First, this paper extends TCP research by exploring the relationship between formal and informal governance structures under a returnee entrepreneurship context. In contrast with some, who argue that formal and informal governance structures are substitutive for each other (e.g. Dyer and Chu, 2003; Uzzi, 1997), this paper agrees with Poppo and Zenger (2002) and finds that these two governance structures complement each other in reducing transaction costs. This shows that REs, a special group of entrepreneurs who are influenced by both western and eastern 
cultures, value the role of both formal and informal governance structures. Second, this study enriches the insights into the SP literature by adopting a new perspective, the perception of entrepreneurs, to evaluate SPs' performance. Traditional studies tend to take the perspective of the SP, rather than the view of entrepreneurs, to analyse SPs' benefits to their tenants. The perspective bias might lead to incomplete or incorrect findings (Phan et al., 2005; Falk, 2007; and Lecluyse et al., 2019). Third, this study is among the first few to demonstrate systematically the mechanism through which SPs' services support REs. The bulk of the existing literature tends to describe the overall effects of SPs on entrepreneurs (e.g. Armanios et al., 2017; Xing et al., 2018), but has not yet figured out the hidden mechanisms underlying those effects. Although some academics analyse the individual influence of SP services, the joint effects of them do not receive enough attention (e.g., Mian, 2014; Minguillo et al,. 2015). This study articulates the (mis)match between SPs' services and REs' transaction costs by mapping out their

relationships. We find that the appropriate combination of NSP services either directly helps REs reduce search costs or indirectly supports REs to reduce contracting, monitoring and enforcement costs through helping them build up governance structures, including legal agreements and guanxi. Finally, this study helps to provide explanations for the dispute among academics on the influence of SPs on entrepreneurs (e.g., Bakouros et al., 2002; Löfsten and Lindelöf, 2002; Tamásy, 2007). This dispute, to some extent, can be attributed to the existing literature's limited understanding of the operation mechanisms of SP services.

\section{Implications for Policy and Practice}

This study provides guidelines for REs and SPs. First, NSPs are counselled not to disperse their energy in developing too many types of services. Instead, they should focus on effectively delivering the four key services with balanced quality: 'mentoring and 
training', 'social event', 'accreditation of RHs' and 'promotion of REs'. The unbalanced service quality might lead NSPs to make much less achievements in reducing REs' costs. Second, this study suggests REs to use the deployment of NSP services as an index to evaluate which SP is the most appropriate location for their new ventures.

\section{Limitations and Future Research}

This study has two main limitations. First, this study collected data from REs in the information technology sector in Chinese context, but REs from other sectors or countries may face different obstacles and as such need different services/support from SPs. Future studies are encouraged to explore how SP should deploy services to help REs in multiple countries and sectors. Second, this is an exploratory qualitative study reliant on the reported perceptions of participants and based on a relatively limited sample size. Future quantitative research, with a bigger sample size and against more objective performance criteria for both SPs and REs' new ventures, is required to confirm or disconfirm the findings of this study. 


\section{References:}

Aldrich, H.E. and Martinez, M.A. (2007), "Many are called, but few are chosen: An evolutionary perspective for the study of entrepreneurship", Entrepreneurship: Concepts, Theory and Perspective, Vol. 25 No. 4, pp. 293-311.

Armanios, D.E., Eesley, C.E., Li, J. and Eisenhardt, K.M. (2017), “How entrepreneurs leverage institutional intermediaries in emerging economies to acquire public resources", Strategic Management Journal, Vol. 38 No. 7, pp. 1373-1390.

Bakouros, Y.L., Mardas, D.C. and Varsakelis, N.C. (2002), "Science park, a high tech fantasy?: An analysis of the science parks of Greece", Technovation, Vol. 22 No. 2, pp. 123-128.

Barthélemy, J. and Quélin, B. V. (2006), “Complexity of Outsourcing Contracts and Ex Post Transaction Costs: An Empirical Investigation", Journal of Management Studies, Blackwell Publishing Ltd, Vol. 43 No. 8, pp. 1775-1797.

Bøllingtoft, A. (2012), “The bottom-up business incubator: Leverage to networking and cooperation practices in a self-generated, entrepreneurial-enabled environment", Technovation, Vol. 32 No. 5, pp. 304-315.

Bøllingtoft, A. and Ulhøi, J.P. (2005), “The networked business incubator: Leveraging entrepreneurial agency?", Journal of Business Venturing, Vol. 20 No. 2, pp. 265290.

Bruneel, J., Ratinho, T., Clarysse, B. and Groen, A. (2012), "The evolution of business incubators: Comparing demand and supply of business incubation services across different incubator generations", Technovation, Vol. 32 No. 2, pp. 110-121.

Carayannis, E.G. and Von Zedtwitz, M. (2005), “Architecting gloCal (global-local), real-virtual incubator networks (G-RVINs) as catalysts and accelerators of entrepreneurship in transitioning and developing economies: Lessons learned and best practices from current development and business incubation ", Technovation, Vol. 25 No. 2, pp. 95-110.

Chan, K.-Y.A., Oerlemans, L.A. and Pretorius, M.W. (2011), "Innovation outcomes of South African New Technology-Based Firms: A contribution to the debate on the performance of science park firms.", South African Journal of Economic and Management Sciences2, University of Pretoria, Vol. 14 No. 4, pp. 361-378. 
Chan, K.F. and Lau, T. (2005), "Assessing technology incubator programs in the science park: The good, the bad and the ugly", Technovation, Vol. 25 No. 10, pp. $1215-1228$.

Chiles, T.H. and McMacking, J.F. (1996), “Integrating Variable Risk Preferences, Trust, and Transactions Cost Economics", Academy of Management Review, Academy of Management, Vol. 21 No. 1, pp. 73-99.

China Business Network Weekly. (2017), “2017 New first-tier cities”, available at: http://www.yicai.com/news/5293378.html.

Coase, R.H. (1937), "The Nature of the Firm”, Economica, Blackwell Publishing Ltd, Vol. 4 No. 16, pp. 386-405.

Colombo, M.G. and Delmastro, M. (2002), "How effective are technology incubators? Evidence from Italy", Research Policy, Vol. 31 No. 7, pp. 1103-1122.

Diez-Vial, I. and Montoro-Sanchez, A. (2017), "Research evolution in science parks and incubators: foundations and new trends", Scientometrics, Vol. 110 No. 3, pp. 1243-1272.

Dyer, J.H. and Chu, W. (2003), "The role of trustworthiness in reducing transaction costs and improving performance: Empirical evidence from the United States, Japan, and Korea", Organization Science, Vol. 23 No. 4, pp. 57-68.

Eisenhardt, K.M. and Graebner, M.E. (2007), "Theory building from cases: Opportunities and challenges", Academy of Management Journal, Academy of Management, Vol. 50 No. 1, pp. 25-32.

Falk, R. (2007), "Measuring the effects of public support schemes on firms' innovation activities. Survey evidence from Austria”, Research Policy, Vol. 36 No. 5, pp. $665-679$.

Filatotchev, I., Liu, X., Buck, T. and Wright, M. (2009), “The export orientation and export performance of high-technology SMEs in emerging markets: The effects of knowledge transfer by returnee entrepreneurs", Journal of International Business Studies, Vol. 40 No. 6, pp. 1005-1021.

Filatotchev, I., Liu, X., Lu, J. and Wright, M. (2011), “Knowledge spillovers through human mobility across national borders: Evidence from Zhongguancun Science Park in China", Research Policy, Vol. 40 No. 3, pp. 453-462. 
Gibbert, M., Ruigrok, W. and Wicki, B. (2008), "What passes as a rigorous case study?", Strategic Management Journal, Vol. 29 No. 13, pp. 1465-1474.

Grimaldi, R. and Grandi, A. (2005), "Business incubators and new venture creation: An assessment of incubating models", Technovation, Vol. 25 No. 2, pp. 111-121.

Gulati, R. (1995), “Does Familiarity Breed Trust? the Implications of Repeated Ties for Contractual Choice in Alliances.", Academy of Management Journal, Vol. 38 No. 1, pp. 85-112.

Hobbs, K.G., Link, A.N. and Scott, J.T. (2017), "Science and technology parks: an annotated and analytical literature review", Journal of Technology Transfer, Vol. 42 No. 4, pp. 957-976.

Hughes, M., Ireland, R.D. and Morgan, R.E. (2007), "Stimulating dynamic value: Social capital and business incubation as a pathway to competitive success", Long Range Planning, Vol. 40 No. 2, pp. 154-177.

Hung, C.F. (2004), “Cultural influence on relationship cultivation strategies:

Multinational companies in China", Journal of Communication Management, Vol. 8 No. 3, pp. 264-281.

Jones Lang LaSalle. (2015), "Top 60 cities of China”, available at: http://www.joneslanglasalle.com.cn/china/zh-cn/Documents/China60/China60CN.pdf (accessed 21 December 2015).

Lecluyse, L., Knockaert, M. and Spithoven, A. (2019), "The contribution of science parks: a literature review and future research agenda", The Journal of Technology Transfer, Vol. 44 No. 2, pp. 559-595.

Lewin, A.Y. and Volberda, H.W. (1999), "Prolegomena on Coevolution: A Framework for Research on Strategy and New Organizational Forms", Organization Science, Vol. 10 No. 5, pp. 519-534.

Li, H., Zhang, Y., Li, Y., Zhou, L.-A. and Zhang, W. (2012), "Returnees versus locals: who perform better in china's technology entrepreneurship?", Strategic Entrepreneurship Journal, Vol. 6 No. 3, pp. 257-272.

Lin, D., Lu, J., Liu, X. and Choi, S.-J. (2014), "Returnee CEO and innovation in Chinese high-tech SMEs BT - Special issue on innovation and entrepreneurship in China”, International Journal of Technology Management, Vol. 65 No. 1-4, pp. 
$151-171$.

Lin, D., Lu, J., Liu, X. and Zhang, X. (2016), “International knowledge brokerage and returnees' entrepreneurial decisions", Journal of International Business Studies, Palgrave Macmillan UK, Vol. 47 No. 3, pp. 295-318.

Lin, D., Wood, L.C. and Lu, Q. (2012), “Improving business incubator service performance in China: the role of networking resources and capabilities", The Service Industries Journal, Vol. 32 No. 13, p. 2091.

Lin, D., Zheng, W., Lu, J., Liu, X. and Wright, M. (2019), "Forgotten or not? Home country embeddedness and returnee entrepreneurship", Journal of World Business, Vol. 54 No. 1, pp. 1-13.

Liu, X., Lu, J. and Choi, S. (2014), "Bridging knowledge gaps: Returnees and reverse knowledge spillovers from Chinese local firms to foreign firms", Management International Review, Springer Berlin Heidelberg, Vol. 54 No. 2, pp. 253-276.

Liu, X., Wright, M., Filatotchev, I., Dai, O. and Lu, J. (2010), "Human mobility and international knowledge spillovers: Evidence from high-tech small and medium enterprises in an emerging market", Strategic Entrepreneurship Journal, John Wiley \& Sons, Ltd., Vol. 4 No. 4, pp. 340-355.

Liu, Y. and Almor, T. (2016), "How culture influences the way entrepreneurs deal with uncertainty in inter-organizational relationships: The case of returnee versus local entrepreneurs in China", International Business Review, Vol. 25 No. 1, pp. 4-14.

Löfsten, H. and Lindelöf, P. (2002), "Science Parks and the growth of new technologybased firms - academic-industry links, innovation and markets", Research Policy, Vol. 31 No. 6, pp. 859-876.

Luo, X.R. and Chung, C.N. (2013), "Filling or abusing the institutional void?

Ownership and management control of public family businesses in an emerging market”, Organization Science, Vol. 24 No. 2, pp. 591-612.

Mian, S.A. (2014), "Business incubation mechanisms and new venture support: Emerging structures of US science parks and incubators", International Journal of Entrepreneurship and Small Business, Inderscience Publishers Ltd, Vol. 23 No. 4, pp. 419-435.

Minguillo, D., Tijssen, R. and Thelwall, M. (2015), "Do science parks promote research 
and technology? A scientometric analysis of the UK", Scientometrics, Springer Netherlands, Vol. 102 No. 1, pp. 701-725.

Ministry of Science and Technology. (2017), Monitoring Report on Key National Science Park, Beijing, China.

Ministry of Science and Technology China. (2006), “The action plan for constructing innovative parks", available at:

http://www.chinatorch.gov.cn/kjb/yaow/200610/5f3d489b429548f5a03c49b6cd92 9f63.shtml (accessed 21 December 2015).

Pasour, E.C. (1991), “Opportunity costs, profits and entrepreneurship”, The South African Journal of Economics, Blackwell Publishing Ltd, Vol. 59 No. 1, pp. 4952.

Peng, M.W. and Heath, P.S. (1996), "The growth of the firm in planned economies in transition: Institutions, organizations, and strategic choice", Academy of Management Review, Academy of Management, Vol. 21 No. 2, pp. 492-528.

Peng, M.W. and Jiang, Y. (2010), "Institutions behind family ownership and control in large firms", Journal of Management Studies, Vol. 47 No. 2, pp. 253-273.

Peters, L., Rice, M. and Sundararajan, M. (2004), "The role of incubators in the entrepreneurial process", The Journal of Technology Transfer, Vol. 29, pp. 83-91.

Phan, P.H., Siegel, D.S. and Wright, M. (2005), "Science parks and incubators: Observations, synthesis and future research", Journal of Business Venturing, Vol. 20 No. 2, pp. 165-182.

Pickernell, D., Packham, G., Jones, P., Miller, C. and Thomas, B. (2011), “Graduate entrepreneurs are different: They access more resources?", International Journal of Entrepreneurial Behaviour and Research, Vol. 17 No. 2, pp. 183-202.

Poppo, L. and Zenger, T. (2002), "Do formal contracts and relational governance function as substitutes or complements?", Strategic Management Journal, John Wiley \& Sons, Ltd., Vol. 23 No. 8, pp. 707-725.

Ratinho, T. and Henriques, E. (2010), "The role of science parks and business incubators in converging countries: Evidence from Portugal”, Technovation, Vol. 30 No. 4, pp. 278-290. 
Sá, C. and Lee, H. (2012), "Science, business, and innovation: Understanding networks in technology-based incubators", $R$ and D Management, Vol. 42 No. 3, pp. 243253.

Scott, W.R. (1987), "The Adolescence of Institutional Theory", Administrative Science Quarterly, Vol. 32 No. 4, pp. 493-511.

Soetanto, D.P. and Jack, S.L. (2013), "Business incubators and the networks of technology-based firms", Journal of Technology Transfer, Vol. 38 No. 4, pp. 432453.

Tamásy, C. (2007), "Rethinking technology-oriented business incubators: Developing a robust policy instrument for entrepreneurship, innovation, and regional development?", Growth and Change, Vol. 38 No. 3, pp. 460-473.

Theodorakopoulos, N., Kakabadse, N.K. and Mcgowan, C. (2014), "What matters in business incubation? A literature review and a suggestion for situated theorising", Journal of Small Business and Enterprise Development, Vol. 21 No. 4, pp. 602622.

Tsang, E.W.K. (1998), "Can guanxi be a source of sustained competitive advantage for doing business in China?", The Academy of Management Executive, Academy of Management, Vol. 12 No. 2, pp. 64-73.

Uzzi, B. (1997), "Social structure and competition in interfirm networks: The paradox of embeddedness", Administrative Science Quarterly, Vol. 42, pp. 35-67.

Voss, C., Tsikriktsis, N. and Frohlich, M. (2002), "Case research in operations management", International Journal of Operations \& Production Management, Vol. 22 No. 2, pp. 195-219.

Walker, G. and Weber, D. (1984), "A transaction cost approach to make-or-buy decisions", Administrative Science Quarterly, Vol. 29 No. 3, p. 373.

Wang, Z., He, Q., Xia, S., Sarpong, D., Xiong, A. and Maas, G. (2020), “Capacities of business incubator and regional innovation performance", Technological Forecasting and Social Change, Vol. 158.

Wang, H. and Liu, Y. (2016), Entrepreneurship and Talent Management from a Global Perspective, Edward Elgar Publishing. 
Wang, H. and Miao, L. (2017), Annual Report on the Development of Chinese Students Studying Abroad, Social Sciences Academic Press (China), Beijing, China, available at: http://www.ccg.org.cn/Research/View.aspx?Id=8120.

Williamson, O. (1985), The Economic Instituions of Capitalism, Simon and Schuster.

Xie, K., Song, Y., Zhang, W., Hao, J., Liu, Z. and Chen, Y. (2018), “Technological entrepreneurship in science parks: A case study of Wuhan Donghu High-Tech Zone”, Technological Forecasting and Social Change, Vol. 135, pp. 156-168.

Xin, K.R. and Pearce, J.L. (1996), "Guanxi: Connections as substitutes for formal institutional support", Academy of Management Journal, Vol. 39 No. 6, pp. 16411658.

Xing, Y., Liu, Y. and Cooper, S.C.L. (2018), "Local Government as Institutional Entrepreneur: Public-Private Collaborative Partnerships in Fostering Regional Entrepreneurship", British Journal of Management, Vol. 00, pp. 1-21.

Yin, R.K. (2009), Case Study Research: Design and Methods, edited by Bickman, L. and Rog, D.J.Essential Guide to Qualitative Methods in Organizational Research, Vol. 5, Sage Publications, London, UK, available at:https://doi.org/10.1097/FCH.0b013e31822dda9e. 
Appendix1: Profile of Interviewees

\begin{tabular}{|c|c|c|c|c|c|c|}
\hline NSP & Code & Interviewee's Job & Gender & $\begin{array}{l}\text { Date } \\
\text { conducted } \\
\text { interview }\end{array}$ & $\begin{array}{l}\text { Year } \\
\text { created } \\
\text { venture } \\
\text { in NSP }\end{array}$ & $\begin{array}{l}\text { Year } \\
\text { returned } \\
\text { China }\end{array}$ \\
\hline \multirow[t]{8}{*}{$\begin{array}{l}\text { NSP- } \\
\text { A }\end{array}$} & A1 & $\begin{array}{l}\text { Head of Innovation } \\
\text { Bureau }\end{array}$ & $\mathrm{M}$ & $5 / 2015$ & & \\
\hline & $\mathrm{A} 2$ & Manager of the Bureau & $\mathrm{F}$ & $5 / 2015$ & & \\
\hline & A3 & Manager of the Bureau & $\mathrm{M}$ & $5 / 2015$ & & \\
\hline & A4 & $\mathrm{CEO}$ & $\mathrm{M}$ & $5 / 2015$ & 2014 & 2013 \\
\hline & A5 & CEO & $\mathrm{M}$ & $5 / 2015$ & 2013 & 2012 \\
\hline & A6 & $\mathrm{CEO}$ & $\mathrm{M}$ & $5 / 2015$ & 2013 & 2013 \\
\hline & A7 & Chairman of Board & $\mathrm{M}$ & $5 / 2015$ & 2013 & 2012 \\
\hline & A8 & CEO & $\mathrm{M}$ & $5 / 2015$ & 2014 & 2014 \\
\hline \multirow[t]{8}{*}{$\begin{array}{l}\text { NSP- } \\
\text { B }\end{array}$} & B1 & $\begin{array}{l}\text { Head of } \\
\text { Entrepreneurship } \\
\text { Service Center }\end{array}$ & $\mathrm{M}$ & $4 / 2015$ & & \\
\hline & $\mathrm{B} 2$ & Manager of the Center & $\mathrm{M}$ & $4 / 2015$ & & \\
\hline & B3 & Manager of the Center & $\mathrm{M}$ & $4 / 2015$ & & \\
\hline & B4 & CEO & $\mathrm{M}$ & $4 / 2015$ & 2013 & 2012 \\
\hline & B5 & CEO & $\mathrm{M}$ & $4 / 2015$ & 2014 & 2014 \\
\hline & B6 & $\mathrm{CEO}$ & $\mathrm{M}$ & $4 / 2015$ & 2014 & 2014 \\
\hline & B7 & $\mathrm{CEO}$ & $\mathrm{F}$ & $4 / 2015$ & 2014 & 2012 \\
\hline & B8 & $\mathrm{CEO}$ & $\mathrm{M}$ & $4 / 2015$ & 2013 & 2013 \\
\hline \multirow[t]{8}{*}{$\begin{array}{l}\text { NSP- } \\
\mathrm{C}\end{array}$} & $\mathrm{C} 1$ & $\begin{array}{l}\text { Head of Innovation } \\
\text { Bureau }\end{array}$ & $\mathrm{M}$ & $3 / 2015$ & & \\
\hline & $\mathrm{C} 2$ & Manager of the Bureau & $\mathrm{M}$ & $3 / 2015$ & & \\
\hline & $\mathrm{C} 3$ & Manager of the Bureau & $\mathrm{F}$ & $3 / 2015$ & & \\
\hline & $\mathrm{C} 4$ & CEO & $\mathrm{M}$ & $3 / 2015$ & 2015 & 2013 \\
\hline & $\mathrm{C} 5$ & $\mathrm{CEO}$ & $\mathrm{M}$ & $3 / 2015$ & 2014 & 2013 \\
\hline & C6 & CEO & $\mathrm{M}$ & $3 / 2015$ & 2014 & 2013 \\
\hline & $\mathrm{C} 7$ & $\mathrm{CEO}$ & $\mathrm{M}$ & $6 / 2015$ & 2015 & 2015 \\
\hline & $\mathrm{C} 8$ & CEO & $\mathrm{M}$ & $6 / 2015$ & 2015 & 2014 \\
\hline
\end{tabular}


Appendix1: (Continued)

\begin{tabular}{|c|c|c|c|c|c|c|}
\hline NSP & Code & Interviewee's Job & Gender & $\begin{array}{l}\text { Date } \\
\text { conducted } \\
\text { interview }\end{array}$ & $\begin{array}{l}\text { Year } \\
\text { created } \\
\text { venture } \\
\text { in NSP }\end{array}$ & $\begin{array}{l}\text { Year } \\
\text { returned } \\
\text { China }\end{array}$ \\
\hline \multirow[t]{10}{*}{$\begin{array}{l}\text { NSP- } \\
\text { D }\end{array}$} & D1 & $\begin{array}{l}\text { Head of Innovation } \\
\text { Centre }\end{array}$ & $\mathrm{M}$ & $11 / 2014$ & & \\
\hline & D2 & Manager of the Center & $\mathrm{M}$ & $11 / 2014$ & & \\
\hline & D3 & Manager of the Center & $\mathrm{M}$ & $1 / 2015$ & & \\
\hline & D4 & CEO & $\mathrm{F}$ & $11 / 2014$ & 2014 & 2013 \\
\hline & D5 & $\mathrm{CEO}$ & $\mathrm{M}$ & $11 / 2014$ & 2015 & 2013 \\
\hline & D6 & CEO & $\mathrm{M}$ & $1 / 2015$ & 2014 & 2012 \\
\hline & D7 & Chairman of Board & M & $1 / 2015$ & 2014 & 2012 \\
\hline & D8 & CEO & $\mathrm{M}$ & $1 / 2015$ & 2015 & 2013 \\
\hline & D9 & CEO & $\mathrm{M}$ & $1 / 2015$ & 2014 & 2014 \\
\hline & D10 & $\mathrm{CEO}$ & M & $1 / 2015$ & 2015 & 2014 \\
\hline \multirow[t]{8}{*}{$\begin{array}{l}\text { NSP- } \\
\text { E }\end{array}$} & E1 & $\begin{array}{l}\text { Head of Innovation } \\
\text { Bureau }\end{array}$ & $\mathrm{M}$ & $4 / 2015$ & & \\
\hline & E2 & Manager of the Bureau & $\mathrm{M}$ & $4 / 2015$ & & \\
\hline & E3 & Manager of the Bureau & $\mathrm{M}$ & $4 / 2015$ & & \\
\hline & E4 & Chairman of Board & $\mathrm{M}$ & $4 / 2015$ & 2013 & 2013 \\
\hline & E5 & $\mathrm{CEO}$ & $\mathrm{M}$ & $4 / 2015$ & 2014 & 2014 \\
\hline & E6 & CEO & $\mathrm{M}$ & $4 / 2015$ & 2015 & 2014 \\
\hline & E7 & CEO & $\mathrm{M}$ & $4 / 2015$ & 2015 & 2015 \\
\hline & E8 & $\mathrm{CEO}$ & $\mathrm{M}$ & $4 / 2015$ & 2015 & 2014 \\
\hline \multirow[t]{7}{*}{$\begin{array}{l}\text { NSP- } \\
\text { F }\end{array}$} & F1 & $\begin{array}{l}\text { Head of Innovation } \\
\text { Service Centre }\end{array}$ & M & $1 / 2015$ & & \\
\hline & F2 & $\begin{array}{l}\text { Staff Member of the } \\
\text { Centre }\end{array}$ & $\mathrm{F}$ & $1 / 2015$ & & \\
\hline & F3 & $\begin{array}{l}\text { Staff Member of the } \\
\text { Centre }\end{array}$ & $\mathrm{F}$ & $1 / 2015$ & & \\
\hline & F4 & $\mathrm{CEO}$ & $\mathrm{M}$ & $1 / 2015$ & 2014 & 2014 \\
\hline & F5 & CEO & $\mathrm{M}$ & $1 / 2015$ & 2015 & 2013 \\
\hline & F6 & CEO & $\mathrm{M}$ & $2 / 2015$ & 2013 & 2012 \\
\hline & F7 & $\mathrm{CEO}$ & $\mathrm{M}$ & $2 / 2015$ & 2015 & 2014 \\
\hline
\end{tabular}




\section{Appendix 2: Semi-Structure Interview Questions for REs}

\begin{tabular}{|c|c|}
\hline \multicolumn{2}{|l|}{ Questions on NSPs' Service } \\
\hline General Services & $\begin{array}{l}\text { 1. Please list this NSPs' services that are closely related to } \\
\text { your resource acquisition from RHs }\end{array}$ \\
\hline $\begin{array}{l}\text { Mentoring \& Training for } \\
\text { REs }\end{array}$ & $\begin{array}{l}\text { 2. Do you think this NSP's service on 'mentoring \& training' } \\
\text { is strong enough to help you acquire resources from RHs? } \\
\text { If so, how? If not, why? }\end{array}$ \\
\hline Accreditation of RHs & $\begin{array}{l}\text { 3. Do you think this NSP's service on 'accreditation of RHs' } \\
\text { is strong enough to help you acquire resources from RHs? } \\
\text { If so, how? If not, why? }\end{array}$ \\
\hline Promotion of REs & $\begin{array}{l}\text { 4. Do you think this NSP's service on 'promotion of you' is } \\
\text { strong enough to help you acquire resources from RHs? If } \\
\text { so, how? If not, why? }\end{array}$ \\
\hline Social Event & $\begin{array}{l}\text { 5. Do you think this NSP's service on 'social event' is strong } \\
\text { enough to help you acquire resources from RHs? If so, } \\
\text { how? If not, why? }\end{array}$ \\
\hline \multicolumn{2}{|c|}{ Questions on Governance Structures } \\
\hline $\begin{array}{l}\text { Finalizing of Legal } \\
\text { Contracts }\end{array}$ & $\begin{array}{l}\text { 6. Do you think this NSP's services are strong enough in } \\
\text { helping you build up legal contracts with RHs? If so, } \\
\text { which service (s) and how? If not, why? }\end{array}$ \\
\hline Building of Guanxi & $\begin{array}{l}\text { 7. Do you think this NSP's services are strong enough in } \\
\text { helping you build up guanxi between RHs and you? If so, } \\
\text { which service (s) and how? If not, why? }\end{array}$ \\
\hline \multicolumn{2}{|l|}{ Questions on Costs } \\
\hline Reduction of Search Cost & $\begin{array}{l}\text { 8. Do you think the services of this NSP are strong enough } \\
\text { in directly helping you reduce costs in searching for } \\
\text { proper RHs? If so, which service (s) and how? If not, why? }\end{array}$ \\
\hline $\begin{array}{l}\text { Reduction of Contracting } \\
\text { Cost }\end{array}$ & $\begin{array}{l}\text { 9. Do you think the services of this NSP are strong enough } \\
\text { in helping you reduce costs related to the negotiation and } \\
\text { establishment of agreements with RHs? If so, which } \\
\text { service (s) and how? If not, why? }\end{array}$ \\
\hline $\begin{array}{l}\text { Reduction of Monitoring } \\
\text { and Enforcement Costs }\end{array}$ & $\begin{array}{l}\text { 10. Do you think the services of this NSP are strong enough } \\
\text { in helping you reduce monitoring and enforcement cost? } \\
\text { If so, which service (s) and how? If not, why? }\end{array}$ \\
\hline
\end{tabular}

\section{Appendix 3: Semi-Structure Interview Questions for Staff Members of NSPs}

\begin{tabular}{|cl|}
\hline \multicolumn{2}{|c|}{ Questions on General support of NSP regarding REs } \\
\hline 1. & Please introduce the general support of this NSP concerning REs' new ventures \\
\hline Questions on NSPs' Services \\
\hline 2. & Please introduce this NSP's services that are closely related to REs' resource acquisition \\
& from RHs \\
\hline 3. & Please introduce this NSP's service relevant to the mentoring \& training for REs. \\
\hline 4. & Please introduce this NSP's service relevant to the accreditation of RHs. \\
\hline 5. & Please introduce this NSP's service relevant to the promotion of RHs. \\
\hline 6. & Please introduce this NSP's service relevant to social events for RHs and REs. \\
\hline
\end{tabular}




\section{Appendix 4 Coding Scheme for Evaluating REs' Opinions}

\begin{tabular}{|c|c|c|c|}
\hline No. & Construct & Perception & Representative Opinions of REs \\
\hline \multirow[t]{2}{*}{1.1} & \multirow[t]{2}{*}{$\begin{array}{l}\text { Mentoring \& } \\
\text { Training for REs }\end{array}$} & $\begin{array}{c}\text { Strong } \\
+\end{array}$ & $\begin{array}{l}\text { 'This NSP's courses are useful to broaden my } \\
\text { knowledge on business negotiation' }\end{array}$ \\
\hline & & $\begin{array}{c}\text { Weak } \\
-\end{array}$ & $\begin{array}{l}\text { 'I did not get much useful skills from this } \\
\text { NSP's training' }\end{array}$ \\
\hline \multirow[t]{2}{*}{1.2} & \multirow[t]{2}{*}{$\begin{array}{l}\text { Accreditation of } \\
\text { RHs }\end{array}$} & $\begin{array}{l}\text { Strong } \\
\quad+\end{array}$ & $\begin{array}{l}\text { 'The recommendation/black list provided by } \\
\text { the NSP is helpful for me to figure out who is } \\
\text { more dependable' }\end{array}$ \\
\hline & & $\begin{array}{c}\text { Weak } \\
-\end{array}$ & $\begin{array}{l}\text { 'This NSP did not have a powerful data base } \\
\text { on prospective collaborators' }\end{array}$ \\
\hline \multirow[t]{2}{*}{1.3} & \multirow[t]{2}{*}{ Promotion of REs } & $\begin{array}{c}\text { Strong } \\
+\end{array}$ & $\begin{array}{l}\text { 'This NSP helped me a lot in increasing the } \\
\text { reputation of myself and my company' }\end{array}$ \\
\hline & & $\begin{array}{c}\text { Weak } \\
-\end{array}$ & $\begin{array}{l}\text { 'I did not feel that this NSP made a significant } \\
\text { difference to my start-up's credibility' }\end{array}$ \\
\hline \multirow[t]{2}{*}{1.4} & \multirow[t]{2}{*}{ Social Events } & $\begin{array}{l}\text { Strong } \\
+\end{array}$ & $\begin{array}{l}\text { 'I established many important links with } \\
\text { business partners via this NSP's social events' }\end{array}$ \\
\hline & & $\begin{array}{c}\text { Weak } \\
-\end{array}$ & $\begin{array}{l}\text { 'This NSP's social events did not enable me to } \\
\text { find enough suitable business partners' }\end{array}$ \\
\hline \multirow[t]{2}{*}{2.1} & \multirow[t]{2}{*}{$\begin{array}{l}\text { Building of Legal } \\
\text { Contracts }\end{array}$} & $\begin{array}{c}\text { Strong } \\
+\end{array}$ & $\begin{array}{l}\text { 'This NSP helped me a lot in developing the } \\
\text { legal contracts between me and my key } \\
\text { business partners' }\end{array}$ \\
\hline & & $\begin{array}{c}\text { Weak } \\
-\end{array}$ & $\begin{array}{l}\text { 'I did not receive much support from the NSP } \\
\text { when I was negotiating and developing the } \\
\text { business agreements with my strategic } \\
\text { business partners' }\end{array}$ \\
\hline \multirow[t]{2}{*}{2.2} & \multirow[t]{2}{*}{$\begin{array}{l}\text { Building of } \\
\text { Guanxi }\end{array}$} & $\begin{array}{l}\text { Strong } \\
\quad+\end{array}$ & $\begin{array}{l}\text { 'This NSP created a comfortable environment } \\
\text { for me to develop guanxi with my business } \\
\text { partners' }\end{array}$ \\
\hline & & $\begin{array}{c}\text { Weak } \\
-\end{array}$ & $\begin{array}{l}\text { 'This NSP did not effectively relieve my } \\
\text { concern on building guanxi with my business } \\
\text { partners' }\end{array}$ \\
\hline \multirow[t]{2}{*}{3.1} & \multirow[t]{2}{*}{$\begin{array}{l}\text { Reduction of } \\
\text { Search Costs }\end{array}$} & $\begin{array}{c}\text { Strong } \\
+\end{array}$ & $\begin{array}{l}\text { 'This NSP offered me a lot help in searching } \\
\text { for prospective business partners' }\end{array}$ \\
\hline & & $\begin{array}{c}\text { Weak } \\
-\end{array}$ & $\begin{array}{l}\text { 'I could not sense enough help from this NSP } \\
\text { when I was looking for business partners' }\end{array}$ \\
\hline \multirow[t]{2}{*}{3.2} & \multirow[t]{2}{*}{$\begin{array}{l}\text { Reduction of } \\
\text { Contracting costs }\end{array}$} & $\begin{array}{l}\text { Strong } \\
\quad+\end{array}$ & $\begin{array}{l}\text { 'This NSP did an effective work to help me } \\
\text { push the negotiation process and develop legal } \\
\text { agreements with my business partners' }\end{array}$ \\
\hline & & $\begin{array}{c}\text { Weak } \\
-\end{array}$ & $\begin{array}{l}\text { 'This NSP did not provide enough support to } \\
\text { the business negotiation with my business } \\
\text { partners' }\end{array}$ \\
\hline \multirow[t]{2}{*}{3.3} & \multirow{2}{*}{$\begin{array}{l}\text { Reduction of } \\
\text { Monitoring and } \\
\text { Enforcement } \\
\text { Costs }\end{array}$} & $\begin{array}{l}\text { Strong } \\
\quad+\end{array}$ & $\begin{array}{l}\text { 'I felt more confident with the enforcement of } \\
\text { the contract with my business partners thanks } \\
\text { to the support of this NSP' }\end{array}$ \\
\hline & & $\begin{array}{c}\text { Weak } \\
-\end{array}$ & $\begin{array}{l}\text { 'I did not feel this NSP provided me with } \\
\text { enough help in pushing my business partners } \\
\text { to fulfill the contract' }\end{array}$ \\
\hline
\end{tabular}


Appendix 5. Further Explanations to Table 7---Within-Case Analysis (Source: created by the authors)

\begin{tabular}{|c|c|c|c|c|c|c|}
\hline 1 NSPs' Service & NSP-A & NSP-B & NSP-C & NSP-D & NSP-E & NSP-F \\
\hline \multirow[t]{2}{*}{ 1.1 Mentoring \& Training for REs } & + & + & + & - & - & - \\
\hline & $\begin{array}{l}\text { REs reflected that } \\
\text { the 'mentoring \& } \\
\text { training' service } \\
\text { gave them precious } \\
\text { opportunities to } \\
\text { not only learn } \\
\text { professional skills } \\
\text { and knowledge on } \\
\text { entrepreneurship, } \\
\text { but also obtain } \\
\text { instructions from } \\
\text { experienced } \\
\text { practitioners or } \\
\text { experts }\end{array}$ & $\begin{array}{l}\text { NSP-B had a } \\
\text { scheme in which } \\
\text { REs could match } \\
\text { with } \\
\text { entrepreneurship } \\
\text { tutors (ETs), such as } \\
\text { local famous } \\
\text { entrepreneurs. }\end{array}$ & $\begin{array}{l}\text { NSP-C worked with } \\
\text { several universities } \\
\text { and professional } \\
\text { agencies to provide } \\
\text { REs with high } \\
\text { quality training } \\
\text { camps with low } \\
\text { charges. }\end{array}$ & $\begin{array}{l}\text { NSP-D did hold } \\
\text { mentoring } \\
\text { programmes and } \\
\text { training schemes, } \\
\text { but the content } \\
\text { was not tailored } \\
\text { enough for REs. }\end{array}$ & $\begin{array}{l}\text { NSP-E's 'mentoring } \\
\text { \& training' service } \\
\text { was not supportive } \\
\text { enough to REs } \\
\text { there. Even though } \\
\text { NSP-E launched a } \\
\text { programme to } \\
\text { match ETs with REs, } \\
\text { the REs were not } \\
\text { satisfied with it. }\end{array}$ & $\begin{array}{l}\text { This science park } \\
\text { had not } \\
\text { established } \\
\text { effective ETs- } \\
\text { schemes nor } \\
\text { regular sessions. } \\
\text { The staff of NSP-F } \\
\text { admitted the } \\
\text { disadvantage in } \\
\text { the mentoring \& } \\
\text { training aspect }\end{array}$ \\
\hline \multirow[t]{2}{*}{ 1.2 Accreditation of $\mathrm{RHs}$} & + & + & - & + & + & - \\
\hline & $\begin{array}{l}\text { Large-scale } \\
\text { database owned by } \\
\text { NSP-A } \\
\text { accommodated } \\
\text { much information } \\
\text { on organizations } \\
\text { that had long } \\
\text { collaborated with } \\
\text { this NSP or the } \\
\text { firms within it. REs } \\
\text { reported that this } \\
\text { service had } \\
\text { reduced them } \\
\text { much time in } \\
\text { looking for and } \\
\text { validating RHs. }\end{array}$ & $\begin{array}{l}\text { The black list } \\
\text { (owned by the NSP) } \\
\text { contained RHs who } \\
\text { severely violated } \\
\text { the contract with or } \\
\text { did serious frauds } \\
\text { to firms within this } \\
\text { science park. This } \\
\text { list was considered } \\
\text { by REs as useful in } \\
\text { avoiding high-risk } \\
\text { collaborators. }\end{array}$ & $\begin{array}{l}\text { The integration of } \\
\text { the information } \\
\text { from different } \\
\text { sources was not } \\
\text { well by this science } \\
\text { park. This divided } \\
\text { database brought } \\
\text { many obstacles to } \\
\text { REs to figure out } \\
\text { the proper RHs for } \\
\text { collaboration. }\end{array}$ & $\begin{array}{l}\text { NSP-D made a } \\
\text { significant } \\
\text { progress in } \\
\text { integrating } \\
\text { information on } \\
\text { RHs from various } \\
\text { sources. REs there } \\
\text { perceived they got } \\
\text { a strong support } \\
\text { from the science } \\
\text { park in evaluating } \\
\text { and figuring out } \\
\text { RHs, although } \\
\text { there still existed } \\
\text { some flaws in this } \\
\text { service }\end{array}$ & $\begin{array}{l}\text { NSP-E began to } \\
\text { imitate successful } \\
\text { experience of some } \\
\text { PWTC-NSPs in } \\
\text { recent years, and } \\
\text { made significant } \\
\text { achievements on } \\
\text { the 'accreditation of } \\
\text { RHs' service. REs } \\
\text { there perceived the } \\
\text { service as useful } \\
\text { since they could } \\
\text { access to some } \\
\text { significant data on } \\
\text { RHs. }\end{array}$ & $\begin{array}{l}\text { It was still very } \\
\text { hard for REs to } \\
\text { verify the } \\
\text { credibility of RHs } \\
\text { before } \\
\text { collaboration. This } \\
\text { science park did } \\
\text { not provide } \\
\text { powerful data } \\
\text { base for REs to } \\
\text { screen the } \\
\text { background of } \\
\text { RHs }\end{array}$ \\
\hline
\end{tabular}




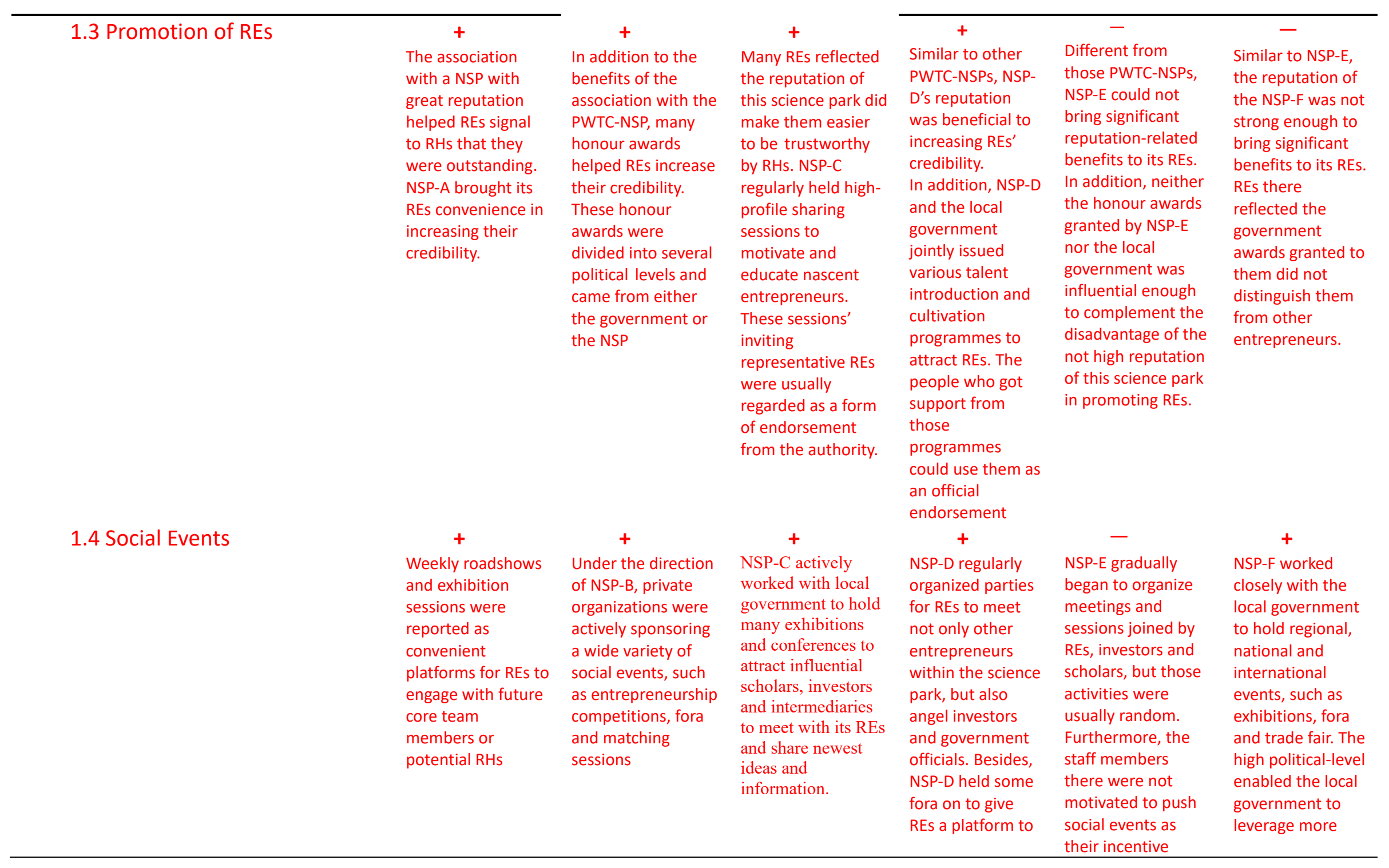




\begin{tabular}{lll}
\hline communicate & mechanism did not & resources to \\
$\begin{array}{l}\text { with professionals } \\
\text { and practitioners }\end{array}$ & emphasize this & support the \\
& & $\begin{array}{l}\text { various social } \\
\text { events. }\end{array}$
\end{tabular}

\section{Note:}

1) All the results are based on the perception of REs in each NSP;

2) In the NSPs' Service Section, ' + ' stands for the services of NSPs are strong, ' - ' stands for the services of NSPs are weak.

3) In the 'Governance Structures' and 'Costs' sections, ' + ' stands for the support of NSPs is strong, ' - ' stands for the support of NSPs is weak

Appendix 5. Further Explanations to Table 7----Within-Case Analysis (Continued)

\begin{tabular}{|c|c|c|c|c|c|c|}
\hline 2 Governance Structures & NSP-A & NSP-B & NSP-C & NSP-D & NSP-E & NSP-F \\
\hline \multirow[t]{2}{*}{ 2.1 Building of Legal Contracts } & + & + & - & - & - & - \\
\hline & $\begin{array}{l}\text { NSP-A helped REs } \\
\text { build legal } \\
\text { contracts by } \\
\text { enabling them to } \\
\text { not only identify } \\
\text { possible pitfalls, } \\
\text { but also specify the } \\
\text { agreement clauses } \\
\text { by more clearly } \\
\text { stating the rights } \\
\text { and } \\
\text { responsibilities, } \\
\text { and probable } \\
\text { contingencies in } \\
\text { the duration of the } \\
\text { contract. }\end{array}$ & $\begin{array}{l}\text { NSP-B regularly } \\
\text { updated a } \\
\text { recommended } \\
\text { package consisting } \\
\text { of contract clauses } \\
\text { and offered it to its } \\
\text { REs with free of } \\
\text { charge. Many REs } \\
\text { agreed this package } \\
\text { can accelerate the } \\
\text { negotiation process } \\
\text { with investors by } \\
\text { making both sides } \\
\text { accept the contract } \\
\text { more easily }\end{array}$ & $\begin{array}{l}\text { REs felt that their } \\
\text { costs on legal } \\
\text { contracts building } \\
\text { did not decrease } \\
\text { significantly, } \\
\text { although NSP-C's } \\
\text { mentoring \& } \\
\text { training on } \\
\text { negotiation did } \\
\text { bring them some } \\
\text { tactics in } \\
\text { developing legal } \\
\text { contracts }\end{array}$ & $\begin{array}{l}\text { Many REs } \\
\text { expressed a } \\
\text { dissatisfaction on } \\
\text { the lack of useful } \\
\text { mentoring \& } \\
\text { training on } \\
\text { business } \\
\text { negotiation. }\end{array}$ & $\begin{array}{l}\text { On the aspect of } \\
\text { legal contract } \\
\text { building, REs there } \\
\text { did not get enough } \\
\text { support from either } \\
\text { NSP-E or } \\
\text { professional } \\
\text { organizations } \\
\text { related to it }\end{array}$ & $\begin{array}{l}\text { This science park } \\
\text { did not provide } \\
\text { strong support to } \\
\text { REs to build up } \\
\text { legal contracts. }\end{array}$ \\
\hline 2.2 Building of Guanxi & + & + & - & + & - & - \\
\hline
\end{tabular}




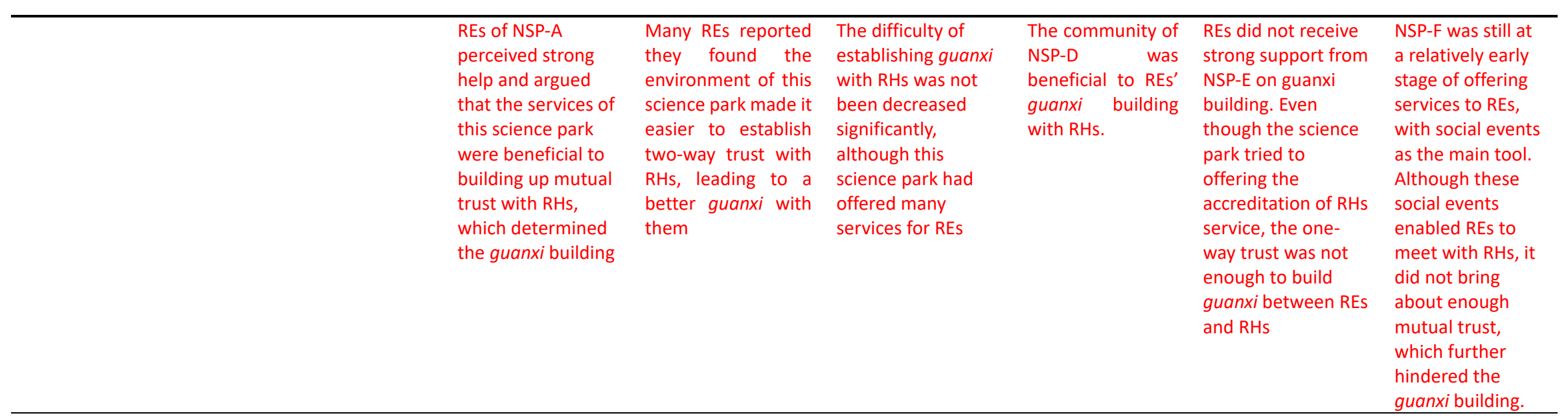

\section{Note:}

1) All the results are based on the perception of REs in each NSP;

2) In the NSPs' Service Section, ' + ' stands for the services of NSPs are strong, ' - ' stands for the services of NSPs are weak.

3) In the 'Governance Structures' and 'Costs' sections, ' + ' stands for the support of NSPs is strong, ' - ' stands for the support of NSPs is weak.

Appendix 5. Further Explanations to Table 7----Within-Case Analysis (Continued)

\begin{tabular}{|c|c|c|c|c|c|c|}
\hline 3 Costs & NSP-A & NSP-B & NSP-C & NSP-D & NSP-E & NSP-F \\
\hline 3.1 Reduction of Search Costs & + & + & - & + & + & - \\
\hline & $\begin{array}{l}\text { NSP-A helped } \\
\text { reduce REs' search } \\
\text { costs by saving }\end{array}$ & $\begin{array}{l}\text { The search costs } \\
\text { were decreased as } \\
\text { NSP-B helped REs }\end{array}$ & $\begin{array}{l}\text { REs reported they } \\
\text { did not find their } \\
\text { search costs was }\end{array}$ & $\begin{array}{l}\text { Many REs } \\
\text { reflected the } \\
\text { accumulated data }\end{array}$ & $\begin{array}{l}\text { NSP-E was } \\
\text { perceived as helpful } \\
\text { by its REs in }\end{array}$ & $\begin{array}{l}\text { NSP-F provided a } \\
\text { successful social } \\
\text { event service, but }\end{array}$ \\
\hline
\end{tabular}




\begin{tabular}{|c|c|c|c|c|c|c|}
\hline & $\begin{array}{l}\text { them much time } \\
\text { and many } \\
\text { resources in } \\
\text { looking for a wide } \\
\text { range of possible } \\
\text { RHs }\end{array}$ & $\begin{array}{l}\text { identify proper RHs } \\
\text { more easily }\end{array}$ & $\begin{array}{l}\text { decreased } \\
\text { significantly } \\
\text { through the help of } \\
\text { NSP-C. }\end{array}$ & $\begin{array}{l}\text { on RHs, which } \\
\text { was sponsored by } \\
\text { the NSP-D, was } \\
\text { useful in directing } \\
\text { them to the } \\
\text { appropriate RHs } \\
\text { group. }\end{array}$ & $\begin{array}{l}\text { reducing search } \\
\text { costs via providing } \\
\text { info on the } \\
\text { background } \mathrm{RHs}\end{array}$ & $\begin{array}{l}\text { it alone could not } \\
\text { ensure a } \\
\text { significant } \\
\text { reduction of } \\
\text { search costs. REs } \\
\text { reported, after } \\
\text { meeting some } \\
\text { RHs, they still } \\
\text { needed to bear } \\
\text { many costs in } \\
\text { searching for their } \\
\text { background to } \\
\text { evaluate their } \\
\text { credibility. }\end{array}$ \\
\hline 3.2 Reduction of Contracting & + & + & - & - & - & - \\
\hline Costs & $\begin{array}{l}\text { REs' contracting } \\
\text { costs were } \\
\text { decreased by NSP- } \\
\text { A's support for } \\
\text { smoothing the } \\
\text { process of } \\
\text { negotiating and } \\
\text { finalizing clauses of } \\
\text { legal contracts }\end{array}$ & $\begin{array}{l}\text { NSP-B's services } \\
\text { were useful in } \\
\text { supporting REs to } \\
\text { accelerate the } \\
\text { contract negotiation } \\
\text { and finalization, and } \\
\text { as such reduce the } \\
\text { contracting costs }\end{array}$ & $\begin{array}{l}\text { REs' contracting } \\
\text { costs was not } \\
\text { reduced } \\
\text { significantly by the } \\
\text { support of NSP-C. } \\
\text { REs there still } \\
\text { tended to adopt } \\
\text { relatively complex } \\
\text { legal contracts to } \\
\text { protect their own } \\
\text { interests, which } \\
\text { incurred significant } \\
\text { time and energy. }\end{array}$ & $\begin{array}{l}\text { Many REs } \\
\text { reported the lack } \\
\text { of high quality } \\
\text { mentoring \& } \\
\text { training could not } \\
\text { effectively } \\
\text { increase their } \\
\text { understanding of } \\
\text { the negotiation } \\
\text { and contract- } \\
\text { related issues, } \\
\text { which led them to } \\
\text { spend much more } \\
\text { time in conceiving } \\
\text { contracts }\end{array}$ & $\begin{array}{l}\text { REs there reflected } \\
\text { they did not feel } \\
\text { evident help from } \\
\text { NSP-E in } \\
\text { accelerating the } \\
\text { contract negotiation } \\
\text { and finalization with } \\
\text { RHs after coming to } \\
\text { this science park. }\end{array}$ & $\begin{array}{l}\text { REs there } \\
\text { reported they did } \\
\text { not receive } \\
\text { enough help in } \\
\text { smoothing the } \\
\text { collaboration } \\
\text { process with RHs. }\end{array}$ \\
\hline 3.3 Reduction of Monitoring and & + & + & - & - & - & - \\
\hline Enforcement Costs & $\begin{array}{l}\text { Many resources } \\
\text { devoting to the } \\
\text { monitoring } \mathrm{RHs} \text { and } \\
\text { enforcing the } \\
\text { contract } \\
\text { implementation }\end{array}$ & $\begin{array}{l}\text { The science park } \\
\text { facilitated the } \\
\text { establishment of } \\
\text { guanxi between REs } \\
\text { and RHs, which } \\
\text { reduced REs' costs }\end{array}$ & $\begin{array}{l}\text { REs reflected their } \\
\text { monitoring and } \\
\text { enforcement costs } \\
\text { were not decreased } \\
\text { evidently through } \\
\text { NSP-C's help, }\end{array}$ & $\begin{array}{l}\text { NSP-D delivered } \\
\text { weak support to } \\
\text { REs' monitoring } \\
\text { and enforcement } \\
\text { costs reduction, } \\
\text { which was similar }\end{array}$ & $\begin{array}{l}\text { In terms of the } \\
\text { costs assigned to } \\
\text { the contract } \\
\text { implementation, } \\
\text { REs found it did not } \\
\text { change significantly }\end{array}$ & $\begin{array}{l}\text { REs of NSP-F } \\
\text { reflected they did } \\
\text { not receive } \\
\text { enough support in }\end{array}$ \\
\hline
\end{tabular}




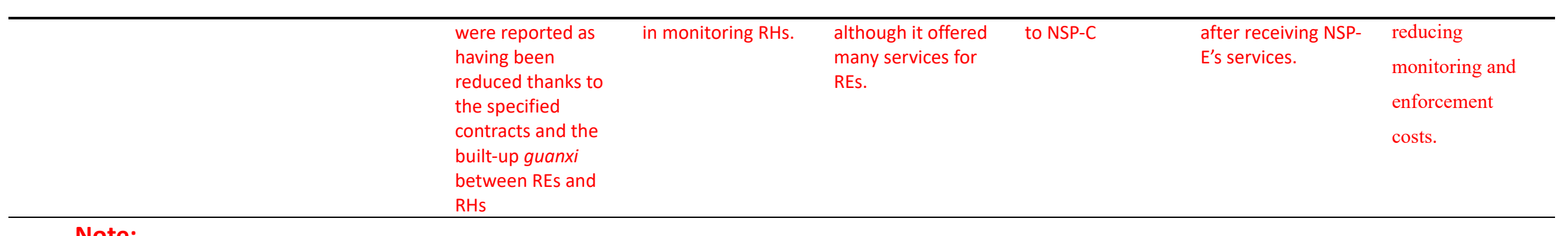

\section{Note:}

1) All the results are based on the perception of REs in each NSP;

2) In the NSPs' Service Section, ' + ' stands for the services of NSPs are strong, ' - ' stands for the services of NSPs are weak.

3) In the 'Governance Structures' and 'Costs' sections, ' + ' stands for the support of NSPs is strong, ' - ' stands for the support of NSPs is weak

\section{Appendix 6 Further Explanations to Figure 2----Cross-Case Analysis}

\begin{tabular}{|c|c|}
\hline & Key points (logic lines) in the comparative analysis across cases \\
\hline $\begin{array}{l}\text { Research Q1: The strong } \\
\text { 'accreditation of RHs' service directly helps } \\
\text { REs reduce search costs. }\end{array}$ & $\begin{array}{l}\text { - A strong service on 'accreditation of RHs' appeared be helpful for REs to } \\
\text { reduce the search costs. For instance, NSP-E offered a strong service on } \\
\text { 'accreditation of RHs' but delivered weak services in other three aspects. REs } \\
\text { of NSP-E regarded this support as an effective shortcut to narrow the journey } \\
\text { of looking for appropriate RHs; } \\
\text { - Without a strong service on 'accreditation of RHs', it appeared hard to reduce } \\
\text { the search costs. For instance, REs from NSPs-C complained that they felt } \\
\text { 'blinded' when looking for potential RHs. NSPs-C offered a weak } \\
\text { 'accreditation of RHs' service but delivered strong services in other three }\end{array}$ \\
\hline
\end{tabular}




\begin{tabular}{|c|c|}
\hline & $\begin{array}{l}\text { - The effectiveness of the 'social event' service on reducing search costs } \\
\text { depended on the presence of other services. The 'social event' service did not } \\
\text { offer sufficient support for REs to screen RHs' background. For instance, the } \\
\text { REs of NSP-F perceived a strong service on 'social event', but REs there } \\
\text { contended they did not get enough support from the NSP in searching for RHs; } \\
\text { There appeared to be little evidence that the 'mentoring and training' service } \\
\text { was an effective tool to reduce search costs of REs. For instance, the REs from } \\
\text { NSP-C perceived little help from the NSP in reducing search costs although } \\
\text { REs thought they got a strong 'mentoring and training' service. } \\
\text { The 'promotion of REs' service could not guarantee the reduction of REs' } \\
\text { search costs. This was supported by REs of NSP-C who felt they were offered } \\
\text { a strong service on 'promotion of REs' from the NSP, but still perceived a weak } \\
\text { help from the NSP in reducing the search costs }\end{array}$ \\
\hline $\begin{array}{l}\text { Research Q2: NSPS effectively help } \\
\text { the guanxi building between REs and RHs by } \\
\text { combining the strong 'promotion of REs', } \\
\text { 'accreditation of RHs' and 'social event' } \\
\text { services. }\end{array}$ & $\begin{array}{l}\text { - Even though 'social event' was important in building guanxi, this service alone } \\
\text { could not, it seemed, guarantee it. For instance, among the four key services, } \\
\text { NSP-F only delivered the strong service on 'social event', but it did not enable } \\
\text { this science park to be helpful in supporting its REs to build guanxi with RHs; } \\
\text { - The 'accreditation of RHs' service helped REs build trust in RHs, but this } \\
\text { service alone could not guarantee the establishment of guanxi between REs and } \\
\text { RHs. For instance, NSP-E offered a strong service on 'accreditation of RHs' } \\
\text { but delivered weak services on three other aspects, and as a result, its REs } \\
\text { reported they tended to trust RHs but it could not ensure the establishment of } \\
\text { guanxi with RHs. } \\
\text { The 'promotion of REs' service could increase REs' credibility, but it required } \\
\text { the coordination of other services if the NSP tended to help build guanxi } \\
\text { between REs and RHs. }\end{array}$ \\
\hline
\end{tabular}




\begin{tabular}{|c|c|}
\hline & $\begin{array}{l}\text { - The combination of 'promotion of REs' and 'social event' services was not } \\
\text { enough to enable NSPs to offer strong support in building guanxi between REs } \\
\text { and RHs. For instance, although NSP-C delivered two strong services on both } \\
\text { 'promotion of REs' and 'social event', its REs still perceived a weak help from } \\
\text { the NSP in building guanxi with RHs. } \\
\text { - The combination of 'promotion of REs' and 'accreditation of RHs', together } \\
\text { with 'social event', enabled NSPs to offer strong help in building guanxi } \\
\text { between REs and RHs. For instance, NSP-A, B and D, which offered strong } \\
\text { services on 'promotion of REs', 'accreditation of RHs' and 'social event' } \\
\text { simultaneously, could bring their REs strong help in the guanxi building. }\end{array}$ \\
\hline $\begin{array}{l}\text { Research Q3: The combination of } \\
\text { strong 'mentoring and training' service and } \\
\text { 'guanxi' enables REs to reduce contracting } \\
\text { costs. }\end{array}$ & $\begin{array}{l}\text { - A relatively strong guanxi could accelerate the contract negotiation between } \\
\text { REs and RHs, but it alone could not significantly reduce the contracting costs. } \\
\text { For instance, NSP-D delivered a strong help in guanxi building but failed to do } \\
\text { so in offering the 'mentoring \& training' service. As a result, its REs reflected } \\
\text { the science park provided a weak support to the contracts building and } \\
\text { contracting costs reduction. } \\
\text { - The 'mentoring \& training' service could help REs speed up the process of } \\
\text { designing a relatively complete and specific contract, but this service alone was } \\
\text { not enough to significantly reduce contracting costs. For instance, NSP-C } \\
\text { offered strong services on mentoring \& training but failed to give its REs strong } \\
\text { help on the guanxi building with RHs. The REs of NSP-C did not perceive a } \\
\text { strong help from the science park in reducing contracting costs and building up } \\
\text { legal contracts. } \\
\text { The combination of 'guanxi' and the 'mentoring and training' service was } \\
\text { beneficial to the contracting costs reduction. For instance, NSP-A and B were } \\
\text { seen to be good at not only delivering a strong service on 'mentoring and } \\
\text { training', but also helping REs build up 'guanxi'. REs of both NSP-A and NSP- } \\
\text { B perceived strong support from their science parks in finalizing legal }\end{array}$ \\
\hline
\end{tabular}




\begin{tabular}{|c|c|}
\hline & contracts. \\
\hline $\begin{array}{l}\text { Research Q4: The combination of } \\
\text { guanxi and legal contracts building effectively } \\
\text { helps reduce REs' monitoring and } \\
\text { enforcement costs. }\end{array}$ & $\begin{array}{l}\text { - Guanxi alone was not effective enough to reduce REs' monitoring and } \\
\text { enforcement. For instance, NSP-D was seen as providing strong support on } \\
\text { guanxi building but not on the legal contracts building. REs there perceived the } \\
\text { NSPs' help as weak in reducing monitoring and enforcement costs. } \\
\text { - It was hard to significantly reduce monitoring and enforcement costs by } \\
\text { adopting legal contracts only. For instance, REs reported that legal contracts } \\
\text { could not substitute for guanxi's role in reducing monitoring and enforcement } \\
\text { costs and that guanxi fundamentally influenced their behaviour, even if they } \\
\text { had stayed in western countries. } \\
\text { When NSPs offered strong help in both the guanxi and legal contracts building, } \\
\text { REs would perceive the science park as helpful in reducing their monitoring } \\
\text { and enforcement costs. Guanxi was seen as useful to make REs and RHs } \\
\text { negotiate in good will. However, legal contracts acted as an ultimate approach } \\
\text { to protect new ventures' vulnerability. For instance, in NSP-A and B, the REs } \\
\text { agreed both guanxi and legal contracts were two crucial and complementary } \\
\text { governance structures to manage the collaboration with RHs. }\end{array}$ \\
\hline
\end{tabular}

